Western New England University School of Law

Digital Commons @ Western New England University School of

Law

Faculty Scholarship

Faculty Publications

2019

\title{
Attorney General v. MIAA at Forty Years: A Critical Examination of Gender Segregation in High School Athletics in Massachusetts
}

Erin E. Buzuvis

Western New England University School of Law, ebuzuvis@law.wne.edu

Follow this and additional works at: https://digitalcommons.law.wne.edu/facschol

Part of the Constitutional Law Commons, and the Law and Gender Commons

\section{Recommended Citation}

Erin E. Buzuvis, Attorney General v. MIAA at Forty Years: A Critical Examination of Gender Segregation in High School Athletics in Massachusetts, 25 TEX. J. C.L. \& C.R. 1 (2019).

This Article is brought to you for free and open access by the Faculty Publications at Digital Commons @ Western New England University School of Law. It has been accepted for inclusion in Faculty Scholarship by an authorized administrator of Digital Commons @ Western New England University School of Law. For more information, please contact pnewcombe@law.wne.edu. 


\title{
Attorney General v. MIAA at Forty Years: A Critical Examination of Gender Segregation in High School Athletics in Massachusetts
}

\author{
Erin E. Buzuvis*
}

I. Massachusetts Constitutional LAW on SEX-SEGREgation IN

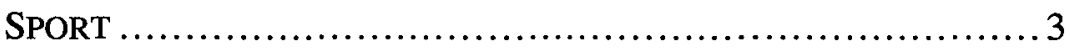

II. Massachusetts Constitutional LaW in CONTEXT ........... 6

A. "Separate but Equal" is the Default Rule in Sport ..........7

B. Girls on Boys' Teams: A (Limited) Exception to the Rule.. 9

C. Boys on Girls' Teams: Almost Never................... 11

III. BENEFITS OF GENDER-FREE ATHLETIC PARTICIPATION ......... 15

A. Segregation and Stigma ........................... 15

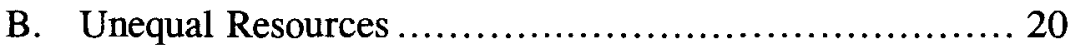

C. Transgender Inclusion ................................ 21

1. Benefits to Transgender Youth..................... 22

2. Benefits to non-binary students .................... 24

IV. DEGENDERING SPORT: START WITH Golf .................... 25

A. Few Female Golfers Currently Benefit from Protectionist Segregation ......................................... 26

B. The (Former) Tournament Rule Discriminated Against Girls on Boys Teams.................................... 27

C. Girls Who Play on Girls' Teams Are Disadvantaged by the

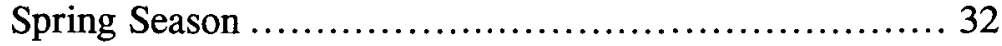

D. Degendered Golf Poses Minimal Risk of Reducing Girls' Participation ........................................... 33

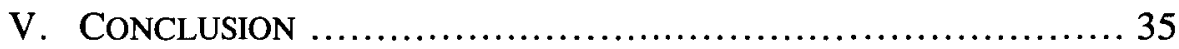

\footnotetext{
* Professor of Law, Western New England University.
} 
High school sports are routinely segregated based on the sex of the participants. ${ }^{1}$ But forty years ago, the highest court in Massachusetts ruled in Attorney General v. Massachusetts Interscholastic Athletic Association that the state constitution's newly-added equal rights amendment prohibited the blanket exclusion of boys from girls' athletic teams. ${ }^{2}$ In this way, state constitutional law in Massachusetts departs from Title IX, as well as that of other states, in providing a legal foundation for a wider selection of gender-integrated high school sports. Yet, while some mixed participation does occur on the margins, athletic opportunities in Massachusetts do not significantly differ from those in other states, in that most remain segregated by sex. Sport organizers in Massachusetts have thus arguably missed an opportunity presented by its unique constitutional law to provide students in the Commonwealth a more balanced menu of athletic opportunities that incorporate both sex-segregated and gender-free sports for the advantages each uniquely provides. As described more fully in Part III, gender-free sport can address logistical challenges posed by segregating boys' and girls' opportunities within the same sport, mitigate the stereotypes of inferior girls' sports, and maximize inclusion of transgender athletes. While segregated sport serves an important role as well-that of protecting and preserving opportunities for female athletes whose interests and abilities have historically and continuously been suppressed-it is time to start thinking not about replacing girls' sports altogether but adding more gender-free sports to the mix. Given its permissive constitutional law on gender integration in sport, Massachusetts would be the perfect state to experiment with a more diverse menu of athletic offerings. At the very least, Massachusetts should identify those sports in which separation does more harm than good, and test whether degendering ${ }^{3}$ sport provides net advantages. Such experimentation would serve not only students in Massachusetts, but in other states as well. Indeed, Massachusetts is unique in the degree to which it resists gender segregation in sport as a matter of constitutional law, but all states are permitted to favor integration more so than they are. Thus, the example that Massachusetts would set by embracing its unique constitutional law is capable of inspiring change throughout the country.

1 See generally Mass. INTERSCHOLASTIC ATHLETIC ASS'N, RULES AND REgUlations Governing ATHLETICS: A HANDBOOK FOR PRINCIPAls AND ATHLETIC DIRECTORS (June 2019), http://www.miaa.net/gen/miaa_generated_bin/documents/basic_mod-

ule/MIAA Handbook19 21.pdf [https://perma.cc/6QBA-FZ34] [hereinafter MIAA HANDBOOK].

2393 N.E.2d $284,29 \overline{6}$ (Mass. 1979).

${ }^{3}$ For the purposes of this article, the author uses the term "degendering" which relates to removing sex and gender as defining characteristics for separating and classifying sports programs. This term is written to be specific to this article, inclusive of non-binary people, and suggestive of co-ed athletic opportunities. This article also uses "gender-free" as shorthand for free from constraints or requirements based on the participants' sex or gender. Gender-free sports are distinguishable from coed sports, which do often take the participants' sex into account, whether it be by imposing a minimum or maximum number of participants of each sex, or otherwise factoring sex into the rules of play. For example, gender-free softball would not insist that batters alternate by sex, as is common in coed softball. Unlike mixed double tennis, gender-free tennis would not require that the server and receiver be of the same sex. 
Part I of this article describes the Supreme Judicial Court's decision in Attorney General v. MIAA and the influence of the state's equal rights amendment in its conclusion that boys cannot categorically be excluded from girls' teams. Part II explains the exceptionalism of Massachusetts constitutional law in the area of gender segregation in sport by comparing Attorney General v. MIAA to Title IX and other courts' interpretation of state constitutional law. Part III suggests that Massachusetts educators should take inspiration from the Supreme Judicial Court's skepticism of the protectionist rationale inherent in sex-segregation and create more gender-free athletic opportunities for high school students in the Commonwealth, which would serve to challenge negative stereotypes about female athleticism, equalize access to resources, and enhance opportunities for transgender students. Finally, Part IV applies the skepticism to the sport of golf in particular and nominates it as a candidate for degendering. Degendering golf would create more opportunities for female golfers to shine against other golfers of all genders, as Emily Nash did in 2017 when she shot the lowest score at the Central Massachusetts Regional Tournament for boys' golf. ${ }^{4}$ It would also curtail the practice of relegating girls' team golf to the suboptimal spring season and provide more opportunities for students to participate in athletics without regard to gender. Finally, any adverse impact on girls' participation that could result from degendering golf could be mitigated by the fact that the rules of team golf are inherent or fixed. Compared to other sports, the scoring of team golf could be creatively reimagined to reward and encourage participation by more diverse team of athletes who contribute different skills.

\section{MASSACHUSETTS CONSTITUTIONAL LAW ON SEX- SEGREGATION IN SPORT}

On November 2, 1976, voters in Massachusetts amended the declaration of rights in the state's constitution, the oldest in the United States, to ensure that "equality under the law shall not be denied or abridged because of sex ...." 5 The political motivation for this amendment came from the national movement to adopt an Equal Rights Amendment ("ERA") to the U.S. Constitution, which Massachusetts had voted to ratify four years earlier. ${ }^{6}$ Though the national movement would ultimately

\footnotetext{
${ }^{4}$ Emily Kay, Dumb rule denies high school golfer Emily Nash her trophy because she's a girl, SBNATION (Oct. 26, 2017), https://www.sbnation.com/golf/2017/10/26/16554750/emily-nash-massachusetts-high-school-golf-boys-tournament-denied-trophy [https://perma.cc/TRM2-YRMC].

${ }^{5}$ MASS. CONST. pt. 1, art. 1, as amended by MASS. CONST. amend. art. 106 ("Equality under the law shall not be denied or abridged because of sex, race, color, creed or national origin. ").

${ }^{6}$ Linda J. Wharton, State Equal Rights Amendments Revisited: Evaluating Their Effectiveness in Advancing Protection Against Sex Discrimination, 36 RUTGERS L.J. 1201, 1201 n.1 (2005)
} 
fail, Massachusetts's ERA immediately curtailed various sex-based distinctions in such realms as child support, ${ }^{7}$ property ownership, ${ }^{8}$ and the criminalization of prostitution. ${ }^{9}$ The subject of gender neutrality in public school athletics, however, proved to be more challenging.

In 1977, a football-coach-turned legislator introduced a bill in the Massachusetts General Assembly's House of Representatives that would prohibit girls from participating in the contact sports of football, wrestling, and ice hockey. ${ }^{10}$ The bill survived review by the education committee over the objection of one its members, Representative Ann C. Gannett. ${ }^{11}$ But before the House could vote on the bill (which had been amended to drop reference to ice hockey), Representative Gannett convinced the body to instead certify a question to the Supreme Judicial Court, seeking an advisory opinion on the bill's constitutionality under the state ERA. ${ }^{12}$ Just over a month later, the Supreme Judicial Court opined that such a blanket prohibition on girls' participation in certain sports would be unconstitutional. ${ }^{13}$ The Court had already concluded in earlier cases that the ERA requires the court to review sex-based classifications by the state with strict scrutiny and accordingly found no compelling state interest in a ban that would categorically prohibit girls from football and wrestling. ${ }^{14}$ It also pointed out that courts routinely strike down policies excluding girls from boys' sports under the U.S. Constitution's equal protection clause, which uses a lower level of scrutiny than the Massachusetts ERA requires. ${ }^{15}$ As a result of the opinion, the legislature dropped consideration of the bill.

Meanwhile, the state's interscholastic athletic association, the Massachusetts Interscholastic Athletic Association (MIAA), was struggling to conform its rules to the ERA as well. ${ }^{16}$ Though the MIAA had long

(explaining that Massachusetts was among the first fourteen states to enshrine equality of the sexes in their constitutions).

${ }^{7}$ Commonwealth. v. MacKenzie, 334 N.E.2d 613, 616--19 (1975).

8 See Mass. Gen. Laws ch. 209, $\$ 1$ (1979) (permitting both spouses a unilateral right to convey property held as tenancy by the entirety).

${ }^{9}$ Commonwealth. v. King, 372 N.E.2d 196, 207 (Mass. 1977).

10 An Act Relative to the Regulations for Participation in School Athletic Programs, House No. 4078, 1977.

${ }^{11}$ Representative Gannett, a Republican from Wayland, was only the $35^{\text {th }}$ woman ever elected to the General Assembly. See Massachusetts Women's Caucus, History of Women in Massachusetts Government (June 13, 2018), http://www.mawomenscaucus.com/history-of-women-in-massachusetts-government/; see, e.g., Letter from Ann. C. Gannett to President Gerald R Ford, (Sept. 9, 1974), https://www. fordlibrarymuseum.gov/library/exhibits/pardon/005601018-010.pdf (criticizing the decision of President Ford-a fellow Republican-to pardon Richard Nixon: "It sickens me to even think that this was the plan all along." ).

12 Mass. Legislative Record (Nov. 21, 1977) House No. 6786 (statement of Rep. Gannett).

13 Op. of the Justices to the H.R., 371 N.E.2d 426, 430 (Mass. 1977).

${ }^{14}$ Id. at $429-430$.

${ }^{15} \mathrm{Id}$.

${ }^{16}$ Mass. Interscholastic Athletic Ass'n, 393 N.E.2d at 287 ("By 1976, evidently reflecting regulations promulgated by the State Board of Education, and, more generally, the adoption of ERA in that year, [the MIAA Rules and Regulations Governing Athletics] had been amended so that a student 
prohibited girls and boys from ever participating on the same teams, it amended this rule to permit both girls and boys to participate on teams designated for the other sex, unless the school provided a "separate but equal" team in that sport. ${ }^{17}$ Consistent with the new rule, one Massachusetts high school permitted boys to play on its girls' softball team, given the absence of a separate softball team for boys. ${ }^{18}$ This prompted protest and litigation, which effectively pressured the MIAA to amend the rule once again. ${ }^{19}$ While retaining the right of girls to try out for boys' team in the absence of a girls' team in their sport, the new rule excluded boys from playing on all girls' teams. ${ }^{20}$ When the MIAA denied waivers to Massachusetts high schools so that their male students could continue to play on girls' teams in a variety of sports, like volleyball, field hockey, and swimming, litigation against the MIAA again ensued, giving the Supreme Judicial Court another opportunity to apply the state's new ERA to high school athletics. ${ }^{21}$

In Attorney General v. Massachusetts Interscholastic Athletic Association, the Supreme Judicial Court concluded that it was unconstitutional to categorically ban boys from girls' teams. ${ }^{22}$ Though the Court implicitly accepted the rule's apparent objectives-ensuring competitive fairness, promoting safety, and preserving athletic opportunities for girls-a compelling justification was, and is today, not enough to survive the scrutiny of sex-based classifications that the ERA requires. ${ }^{23}$ The state must also use narrowly-tailored means that inflict the least discrimination possible. ${ }^{24}$ MIAA's arguments in support of the rule, however, were "replete with stereotypical assumptions and generalities" about the weakness and fragility of female athletes. ${ }^{25}$ While competitive fairness and safety are achieved by grouping athletes by functional ability, the Court reasoned, sex is an imperfect proxy for function, ${ }^{26}$ even if "biological circumstances" confer a competitive advantage on boys in general. ${ }^{27}$ The Court reasoned:

The general male athletic superiority based on physical features is challenged by the development in increasing numbers of female athletes whose abilities exceed those of most men,

could not be barred from competing for a place on a team because of sex unless the school provided a 'separate but equal' team.").

${ }^{17} I d$.

${ }^{18} I d$.

${ }^{19} \mathrm{Id}$.

${ }^{20} I d$.

${ }^{21} I d$. at 288.

${ }^{22}$ Id. at 296.

${ }^{23}$ Id. at 291.

${ }^{24}$ Id.

25 Id. at 294.

${ }^{26}$ Id. at 293.

${ }^{27}$ Id. 
and in some cases approach those of the most talented men. Coordination, concentration, strategic acumen, and technique or form (capabilities of both sexes) intermix with strength and speed (where males have some biologic advantages) to produce athletic results. Classification on strict grounds of sex, without reference to actual skill differentials in particular sports, would merely echo "archaic and overbroad generalizations. $" 28$

The MIAA's final argument was that the rule was necessary to protect girls from being edged out of their own teams as they became "swamped" with male players. ${ }^{29}$ But the Court was unwilling to credit the speculation that female athletes were categorically vulnerable to displacement by more athletic boys. ${ }^{30}$ Perhaps especially in female-dominant sports, the court reasoned that female athletes will generally hold on to their spots by virtue of their athletic talent. ${ }^{31}$ The Court singled out gymnastics, swimming, and riflery as sports where it assumed boys were unlikely to have a competitive advantage. ${ }^{32}$ Moreover, if permitting crossover tryouts for boys did in fact prove over time to reduce the number of athletic opportunities for girls, there are other less discriminatory means to address the problem. For example, the Court suggested the MIAA could cap the number of boys who could play on a girls' team or restrict participation to boys whose height, weight, and skill were within the range of their female competition. ${ }^{33}$ The Court even suggested that "[a]dmission could perhaps be regulated by handicapping in a sport like golf. "34 Additionally, the Court emphasized that a separate boys team could always be a "backstop" to these alternatives: "if enough boys are interested in a sport to try out for, and threaten to oust girl players from a particular team, the school authorities are on notice that a boys' team may be in order." 35

\section{MASSAChuSETtS CONSTITUTIONAL LAW IN CONTEXT}

To understand the uniqueness of Massachusetts constitutional law on gender and sports, it is necessary to consider the legal context of sexsegregated athletics, then and now. First, the Court's advisory opinion on crossover participation by girls is not revolutionary, but it's largely

\footnotetext{
${ }^{28} \mathrm{Id}$. (citation omitted).

${ }^{29}$ Id. at 294.

${ }^{30} \mathrm{Id}$.

${ }^{31} I d$. at 294-95.

${ }^{32}$ Id. at 295 .

${ }^{33} \mathrm{Id}$.

${ }^{34}$ Id.

${ }^{35}$ Id.
} 
consistent with the mainstream of cases decided under federal and other states' constitutional law. ${ }^{36}$ Neither is the fact that the Court offered no objection-not in its advisory opinion on the crossover participation rights of girls, nor in its decision in Attorney General v. MIAA securing a limited crossover participation right of boys-to the practice of segregating athletes by sex in the first place. ${ }^{37}$ But the Court's decision in Attorney General v. MIAA, its refusal to engage in generalizations and stereotypes about inferior female athleticism, and its imagining of creative possibilities for integration provides a roadmap to some experimentation with gender-free sport-an opportunity that the MIAA and its member schools have never pursued..$^{38}$

\section{A. "Separate but Equal" is the Default Rule in Sport}

Massachusetts is not unique in endorsing the default principle that athletics may permissibly be segregated by sex. ${ }^{39}$ The pervasiveness and entrenchment of the separate-but-equal approach to sex equity in athletics is largely attributable to Title IX, the federal law passed in 1972 to prohibit sex discrimination in education..$^{40}$ The statute itself is silent with regard to its application to collegiate and scholastic athletics, but its implementing regulations, ${ }^{41}$ enforced by the Department of Education's Office for Civil Rights, supply additional detail. Though these regulations do not require educational institutions to offer separate male and female athletics programs, they do permit, and thereby and normalize, them. ${ }^{42}$

\footnotetext{
${ }^{36}$ See, e.g., Darrin v. Gould, 540 P.2d 882, 893 (Wash. 1975) ("The WIAA rule forbidding qualified girls from playing on the high school football team in interscholastic competition cannot be used to deny the [appellants], and girls like them, the right to participate as members of that team. "); Brenden v. Indep. Sch. Dist., 477 F.2d 1292, 1302 (8th Cir. 1973) (reversing Minnesota high school ruie that disailiowed females from playing on male teams); Leffel $v$. Wis. Interscholastic Athletic Ass'n, 444 F. Supp. 1117, 1123 (E.D. Wis. 1978) (holding that prohibition on females competing on male teams to be Equal Protection Clause violation).

${ }^{37}$ See, e.g., Yellow Springs Exempted Village Sch. Dist. Bd. of Ed. v. Ohio High Sch. Athletic Ass' $n ., 647$ F.2d 651, 657 (6th Cir. 1981) ("To hold that a recipient of federal aid may let girls at the middle school level compete on the same team with boys, if this furthers the goal of equal athletic opportunity, is not to hold that all teams must be coeducational at all levels . . ..").

${ }^{38}$ Mass. Interscholastic Athletic Ass'n, 393 N.E.2d at 295. ("[T] he rule overlooks approaches . . . that could solve any anticipated problem of boys in substantial numbers displacing girls from competition. . . Use of standards focusing on height, weight, or skill rather than solely on gender represents one such approach ....").

${ }^{39}$ See discussion infra subparts II(B), II(C). Courts outside of Massachusetts have justified permissible sex-segregated sports on a variety of grounds. See, e.g., Hoover v. Meiklejohn, $430 \mathrm{~F}$. Supp. 164 (D. Colo. 1977) (justifying ruling against female soccer players based on discretion of schools); Cape v. Tenn. Secondary Sch. Athletic Assoc., 563 F.2d 793 (6th Cir. 1977) (justifying exclusion of female from a high school boys' basketball team based on physical differences between the sexes).

${ }^{40}$ See 20 U.S.C. 1681(a) (2012) ("No person in the United States shall, on the basis of sex, be excluded from participation in, be denied the benefits of, or be subjected to discrimination under any education program or activity receiving Federal financial assistance . . . .").

4134 C.F.R. $\$ 106.41$ (2018).

${ }^{42} I d . \S 106.41$ (b) ("[A] recipient may operate or sponsor separate teams for members of each sex ....")
} 
Permission to operate sex- segregated athletics programs extends broadly to those teams for which "[the] selection ... is based upon competitive skill or the activity involved is a contact sport, ${ }^{43}$ which is to say, any sport with a tryout process (including interscholastic and intercollegiate programs) as well as teams that are open to all-comers if the sport in question is a contact sport. ${ }^{44}$ The regulations and associated policies normalize sex-segregation by devoting the majority of their focus to the requirements for equitable treatment of the separate programs $\mathrm{s}^{45}$ and by limiting the right of girls to play with boys and vice versa (so called "crossover participation") to a narrow range of circumstances, discussed in the next subpart. Title IX and its associated regulations and policies have tremendous effect on cultural norms, as well as institutional behavior. ${ }^{46}$ While prior to Title IX some educational institutions had experimented with gender-free athletic opportunities, today nearly all interscholastic or intercollegiate sports are designated male or female. In the 1970 s, some women's sports advocates argued for integrated athletic opportunities ${ }^{47}$ a position that is rarely taken today.

It is interesting that "separate-but-equal" justifications for gender and sport are accepted today, given that Title IX and equal protection doctrine apply formal equality mandates to other contexts, like admissions and employment. The adoption and endurance of the separate-butequal justification reflect generalizations and stereotypes about female athleticism, to be sure. But it also reflects a pragmatic concern that separate opportunities for women and girls were necessary to overcome a history of women's exclusion from sport, and the resulting suppression of their athletic interests and abilities. ${ }^{48}$ Even Massachusetts, with the broadest rights to crossover participation of any state, does not challenge the practice of segregating high school sports by sex as a general rule. In Attorney General v. MIAA, the Supreme Judicial Court at least implicitly acknowledged that preserving opportunities for previously underserved girls is a compelling state interest. ${ }^{49}$ This interest is served by the 'separate but equal' approach but is only constitutional if it minimizes sex-based exclusions to the greatest extent possible. Thus, in ruling that

${ }^{43} \mathrm{Id}$.

${ }^{44} \mathrm{Id}$.

${ }^{45}$ See id. § 106.41(c) ; 1979 Policy Interpretation; 1996 Clarification.

${ }^{46}$ Deborah Brake, The Struggle for Sex Equality in Sport and the Theory Behind Title IX, $34 \mathrm{U}$. MICH. J.L. REFORM 13, 18 (2001) ("In short, opportunities for female athletes are at an all-time high, and public interest in and support for women's sports has never been greater. The changes in women's sports participation have been accompanied by significant cultural change. . . . Title IX has played a large, if unquantifiable role in this cultural shift and the new opportunities that made it possible.").

${ }^{47}$ EIleen McDonagh \& Laura Pappano, Playing With the Boys: Why Separate Is Not EQUAL IN SPORTS 213-14 (2008).

${ }^{48}$ See generally DEBORAH BRAKE, GETTING IN THE GAME: TITLE IX AND THE WOMEN'S SPORTS REVOLUTION 15-39 (2010) (describing several justifications for separate-but-equal gender opportunities in sports).

${ }^{49}$ See Mass. Interscholastic Athletic Ass'n, 393 N.E.2d at 295 (having discussed the criteria for sex-based classifications to survive judicial review, the court nonetheless felt the need to state that "the legality of separate but equal teams is not challenged here."). 
some crossover participation be allowed, the Court is not contradicting sex-segregated athletics, but is instead creating the conditions by which it is possible to uphold the practice as a general rule.

\section{B. Girls on Boys' Teams: A (Limited) Exception to the Rule}

Massachusetts is also not unique in endorsing the right of girls to try out for boys' teams. ${ }^{50}$ Title IX and equal protection doctrine both support at least a limited right of crossover participation by girls. Title IX's regulatory provision governing crossover participation mandates that an athlete be permitted to try out for a team of the other sex when the following three conditions are satisfied: (1) the school already offers a team in that sport to members of the sex opposite to that of the athlete, ${ }^{51}$ (2) "opportunities in that athlete's sex have previously been limited," 52 and (3) the sport in question is not a contact sport. ${ }^{53}$ This statutory mandate for permitting crossover participation has brought more athletic opportunities for females: though athletic opportunities for high school girls has increased more than 10 -fold since the 1970 s, the share of athletic opportunities allocated to girls has never been higher than $44.5 \% .{ }^{54}$ It is likely that at nearly all coed high schools, girls' athletic opportunities have previously been limited, and even continue to be so. Therefore, a girl at a school with only a boys' golf team, for example, would have the same opportunity as boys to pursue a position on the team.

Due to the regulatory exception for contact sports, however, that girl would not have a right under Title IX to try out for the school's only football team. ${ }^{55}$ But courts applying the equal protection doctrine have been less willing to endorse the contact sports limitation, and have recognized the right of girls to try out for boys' teams in both contact and

${ }^{50}$ See, e.g., Darrin, 540 P.2d at 893 ("The WIAA rule forbidding qualified girls from playing on the high school football team in interscholastic competition cannot be used to deny the [appellants], and girls like them, the right to participate as members of that team.").

${ }^{51} 34$ C.F.R. $\$ 106.41$ (b) (2018).

52 Id. Some have argued that the "historically limited" be interpreted to permit boys' right to a crossover tryout in sports where their opportunities are historically limited. See Gomes v. Rhode Island Interscholastic League, 469 F. Supp. 659, 665-66 (D.R.I. 1979), vacated as moot, 604 F.2d 733 (1st Cir. 1979); see also Adam S. Darowski, For Kenny Who Wanted to Play Women's Field Hockey, 12 DUKE J. GENDER L. \& POL'Y 153, 162 (2005).

5334 C.F.R. $\$ 106.41$ (b) (2018) (noting contact sports are defined in the regulations as "boxing, wrestling, rugby, ice hockey, football, basketball and other sports the purpose or major activity of which involves bodily contact.").

54 National FEDERATION OF HIGH Schools, Participation Statistics 2016-17, http://www.nfhs.org/ParticipationStatistics/PDF/2016-17_Participation_Survey_Results.pdf (noting the percentage of athletic opportunities available to women in 2016-2017).

s5 34 C.F.R. \$ 106.41(b) (2018) ("[A] recipient may operate or sponsor separate teams for members of each sex where selection for such teams is based upon competitive skill or the activity involved is a contact sport."). 
noncontact sports. ${ }^{56}$ The Massachusetts Supreme Judicial Court opined that a rule banning girls from the contact sports of wrestling and football would never survive the strict scrutiny that Massachusetts applies to distinctions based on sex. ${ }^{57}$ Similarly, courts applying intermediate scrutiny have rejected attempts to exclude girls from boys' teams based on generalizations about inferior female athleticism and diminished size and strength on the grounds that those justifications are inconsistently applied. ${ }^{58}$

On the other hand, courts have found that equal protection doctrine mirrors Title IX's restriction of female crossover participation to sports in which there is an available girls' team. For example, the Seventh Circuit Court of Appeals ruled that an exceptionally talented female basketball player named Karen O'Connor did not have a constitutional right to try out for a boys' basketball team because the school sponsored a separate girls team in that sport. ${ }^{59}$ The court's decision, along with Justice Stevens's single-Justice opinion on appeal from a ruling involving preliminary relief, ${ }^{60}$ confirmed that the law sublimated $O^{\prime}$ Connor's individual right to an opportunity suited to her talents to the broader interest in order to protect female athletic opportunities through the separate-butequal approach.$^{61}$ This distinction was necessary, as Justice Stevens put it, to address the "substantial risk that boys would dominate the girls' programs and deny them an equal opportunity to compete in interscholastic events. "62 This limitation is designed to protect the rights of female athletes as a group. ${ }^{63}$ Women's separate athletic programs offer female

${ }_{56}$ See, e.g., Adams v. Baker, 919 F. Supp. 1496, 1504 (D. Kan. 1996) (wrestling); Force v. Pierce City R-VI Sch. Dist., 570 F. Supp. 1020, 1031-32 (W.D. Mo. 1983) (football). See also B. Glenn George, Fifty/Fifty: Ending Sex Segregation in School Sports, 63 OHIO ST. L.J. 1107, 1125 (2002). The tendency of some courts to affirm female athletes' equal protection right to participate on boys' teams in contact sports (absent a girl team in that sport) neutralizes Title IX's contact sports exemption where state-sponsored athletic programs are concerned in those jurisdictions. See Suzanne Sangree, Title IX and the Contact Sports Exemption: Gender Stereotypes in a Civil Rights Statute, 32 CONN. L. REV. 381 (2000); George, supra at 1127 (pointing out that courts have not enjoined the contact sports exemption itself because it merely permits, not requires, conduct that violates the Equal Protection Clause).

57 See supra Part I.

58 Adams, 919 F. Supp. at 1500 (noting that the state's rules do not require girls to lift 200 pounds to wrestle, while in some instances men must, though boys are not required to do so in this case).

${ }^{59} \mathrm{O}^{\prime}$ Connor v. Bd. of Educ., 645 F.2d 578, 582-83 (7th Cir. 1981).

60 See generally O'Connor v. Bd. of Educ., 449 U.S. 1301 (1980). The Court of Appeals stayed the preliminary injunction that $O^{\prime}$ Connor had obtained from the district court. $O^{\prime}$ Connor petitioned the Supreme Court to vacate the stay, which Justice Stevens denied in his capacity as Circuit Justice. Id. at 1301. This decision remains the closest the Supreme Court has ever gotten to addressing the legality of sex segregation in athletics.

${ }^{61} O^{\prime}$ Connor, 449 U.S. at 1307; see also $O^{\prime}$ Connor, 645 F.2d at 581-82 (quoting Justice Stevens and making the same point).

$62 O^{\prime}$ Connor, 449 U.S. at 1307.

${ }^{63}$ See 34 C.F.R. $\S 106.41$ (c) (2018) (stating the criteria for equal opportunity in terms of provisions for "members of" groups, not individuals); Courtney W. Howland, Sex Discrimination and Intercollegiate Athletics: Putting Some Muscle on Title IX, 88 YALE L. J. 1254, 1265 (1979) ("The development of the woman athlete thus requires equality of participation in group athletics. Although equality on an individual basis might simply demand sex-blind sports teams, equality on a group basis demands more."). 
athletes the opportunity to compete that they might not have if athletic opportunities were distributed solely on the basis of talent and interest, since the historic exclusion of girls and women from sport suppressed their interests and talents in athletics in the first place. This objective is arguably incompatible with strong protection for individual talented female athletes to engage in crossover participation, for two reasons. First, schools might be deterred from adding girls' teams in the first place if not for the fact that doing so creates a legal and socially acceptable way to prevent girls from trying out for boys' teams. Second, a broad right to crossover participation could undermine girls' sports by permitting the most talented girls to bypass rather than establish them as a legitimate purveyor of interest and talent.

In Massachusetts as well, girls' right to participation on boys' teams-as well as the reciprocal right of boys, discussed below-is limited to those athletes for whom the school does not provide a team in that sport to members of the athlete's sex.$^{64}$ Courts in Massachusetts have never had the opportunity to address the compatibility of this limitation with the state ERA.

\section{Boys on Girls' Teams: Almost Never}

Massachusetts law is unique in recognizing a right of boys to try out for girls' teams. ${ }^{65}$ Until recently, the MIAA rule implementing the Supreme Judicial Court's decision in Attorney General v. MIAA read, "A girl may play on a boys' team if that sport is not offered in the school for the girl, and a boy may play on a girls' team if that sport is not offered in the school for the boy." ${ }^{66}$ Recent revisions to the MIAA handbook confirmed that this right can be limited in situations where necessary to preserve opportunities for girls in the interest of Title IX compliance ${ }^{67}-$ a clarification likely responsive to pressure resulting from complaints to the Department of Education's Office for Civil Rights (hereafter "OCR" ${ }^{68}$ that the application of MIAA's rule permitting boys on girls'

${ }^{64}$ MIAA HANDBOOK, supra note 1, at 42 . Rule 43.2 and 43.3 of the MIAA's Rules and Regulations Governing Athletes state:

43.2.If a school offers a single team in a particular sport, it may not restrict eligibility based on gender unless such a restriction is necessary to ensure that the school's gendered designation of athletic opportunities complies with Title IX (either by demonstrating proportionality or the absence of unmet interest among members of the underrepresented sex).

43.3.If a school offers a girls' team and a boys' team in a particular sport (including offering the same sport in two different seasons), it may restrict eligibility based on gender.

Id. The language permitting schools to exclude boys from girls' teams if necessary for Title IX compliance went into effect in 2019. Id. at 4.

${ }^{65} \mathrm{Id}$. at 4,42 .

${ }^{66} \mathrm{Id}$. at 4.

${ }^{67} \mathrm{Id}$. at 4,42 .

${ }^{68}$ Bob Holmes, MIAA receives complaint over boys playing field hockey, BoS. GLOBE (Sept. 28, 
field hockey teams deprives girls of opportunities in violation of Title IX. Considering the three alternative routes that schools may take to demonstrate compliance in their distribution of athletic opportunities by sex, a school would only be permitted to exclude a boy from the only team in the sport if (1) girls are underrepresented in athletic opportunities (violation of the first test), (2) there is no history and continuing practice of adding opportunities for girls (violation of the second test), and (3) the presence of a boy on the team displaces a girl from the team who otherwise would have qualified for the team (and therefore constitutes "unmet interest" in violation of the third compliance test).$^{69}$ At schools where the first or second tests are satisfied, or where the team in question does not cut players, boys still have the right to try out for girls' teams. ${ }^{70}$

Even with the recent qualification for Title IX compliance, boys' rights to participate on girls' teams in sports for which no boys' teams exist is still broader than under Title IX. Title IX, in contrast, limits crossover participation to athletes for whom athletic opportunities have "previously been limited ... ."71 Though commentators have discussed a sport-specific interpretation of this requirement that would give boys an opportunity to try out for sports that have been historically limited to girls, ${ }^{72}$ only one federal court has ever endorsed this position, in a preliminary injunction analysis that was later vacated as moot. ${ }^{73}$ Instead, the prevailing view seems to be that the regulation requires the participants' athletic opportunities in general to have been historically limited at the participants' schools. ${ }^{74}$ As noted above, this interpretation will rarely if ever apply to boys. Even if a boy did successfully manage to mount this hurdle, he would still only have the right to participate in non-contact sports in which his school did not sponsor a boys' team.

Boys outside of Massachusetts have also had relatively little success using equal protection doctrine to secure their right to play on girls' teams. ${ }^{75}$ Courts applying intermediate scrutiny required by the

2012), https://www.boston.com/sports/untagged/2012/09/28/miaa-receives-us-complaint-overboys-playing-field-hockey [https://perma.cc/2Z33-WDAT]; see also Christopher Marquis, An Equal Playing Field: The Potential Conflict Between Title IX \& the Massachusetts Equal Rights Amendment, 34 B.C.J.L. \& SoC. JUST. 77, 79 (2014) (describing the complaint issued by the Office of Civil Rights to the MIAA).

${ }^{69}$ Title IX of the Education Amendments of 1972; a Policy Interpretation; Title IX and Intercollegiate Athletics, 44 Fed. Reg. 71,413, 71,418 (Dec. 11, 1979).

$70 \mathrm{Id}$.

7134 C.F.R. \& 106.41(b) (2018).

${ }^{2}$ Kleczek v. Rhode Island Interscholastic League, 768 F. Supp. 951, 955 (D.R.1. 1991); Darowski, supra note 52, at 162-65; Sangree, supra note 56, at 390 ("However, with respect to allfemale teams, the majority of courts have declined to order that males be allowed to try out because they cannot establish a history of exclusion from sports opportunities. ").

${ }^{73}$ Gomes, 469 F. Supp. at 664-66.

${ }^{74}$ Williams v. Sch. Dist. of Bethlehem, Pa., 998 F.2d 168, 174 (3d Cir. 1993); Mularadelis v. Haldane Cent. Sch. Bd., 74 A.D.2d 248, 256 (N.Y. App. Div. 1980).

${ }^{75}$ Clark v. Ariz. Interscholastic Ass'n, 695 F.2d 1126, 1131-32 (9th Cir. 1982); Kleczek v. R.I. Interscholastic League, 768 F. Supp. 951, 955 (D.R.I. 1991); B.C. v. Bd. of Educ., Cumberland 
Fourteenth Amendment have generally reasoned that redressing past discrimination against girls is an important objective and that the categorical exclusion of boys from girls' teams suitably serves this objective by protecting existing opportunities from displacement by more athletic boys. ${ }^{76}$ Courts considering state constitutional claims have reached similar conclusions, ${ }^{77}$ even in states that, like Massachusetts, apply strict scrutiny of sex-based designations. ${ }^{78}$ Thus, the rights of girls as a group to have separate athletic opportunities is elevated above both the rights of individual girls who may be better served by the boys' team and of individual boys to play sports only offered to girls. ${ }^{79}$

However, there is one notable exception of a recent decision applying equal protection principles in boys' favor. In March 2019, the Eighth Circuit Court of Appeals ordered a preliminary injunction against the Minnesota state interscholastic athletic association's rule that prohibited boys from participating on competitive dance teams. ${ }^{80}$ The court reasoned that the plaintiffs had a likelihood of success on the merits because statewide participation data showed very similar rates of athletic participation by boys and girls, ${ }^{81}$ calling into question the persuasiveness of the association's justification for treating students differently on the basis of sex. ${ }^{82}$ Subsequent to the decision, the association changed the rule after settling the case,$^{83}$ though it is still too soon to tell whether this case is an outlier rooted in potentially unique facts of Minnesota's equitable participation data or the beginning of a shift in favor of integrating former girls' sports.

Unless or until such shift occurs, the Supreme Judicial Court's

Reg'l Sch. Dist., 531 A.2d 1059, 1066 (N.J. Super. Ct. App. Div. 1987) (addressing only state claims, as it is not a federal court); Petrie v. Ill. High Sch. Athletic Ass'n, 394 N.E.2d 855 (Ill. App. Ct. 1979) (citing People v. Ellis, 311 N.E.2d 98 (T11. 1974)).

${ }^{76}$ Clark, 695 F.2d at 1131; Kleczek, 768 F. Supp. at 955-56.

${ }^{\pi}$ Klezcek, 768 F. Supp. at 955-56; B.C. v. Bd. of Educ., 531 A.2d at 1065-66 (addressing only state claims, as it is not a federal court).

${ }^{78}$ Petrie, 394 N.E.2d at 858-59 (citing People v. Ellis, 311 N.E.2d 98 (Ill. 1974)).

${ }^{79}$ Parenthetically, one issue that seems to be underexamined by all courts considering equal protection or Title IX claims by boys is that the concern about boys swamping girls' teams has an outer limit in Title IX. Even if boys did in fact displace girls from opportunities that they had previously enjoyed, Title IX would operate in many such cases to require schools to replace those opportunities since an equitable distribution of athletic opportunities is still required in those circumstances. A school whose girls' volleyball team has been displaced by boys, for example, would be legally compelled to add another girls' volleyball team to ensure that the overall distribution of athletic opportunities remains proportionate to the gender breakdown of the student body. That school might also need to eliminate a boys' team as well to attain proportionality, since the original girls' volleyball team itself probably existed to balance out some other boys' team. But the result might be athletic opportunities more aligned with the actual interest of boys who just (in this hypothetical) wanted to play volleyball so badly that they took over the girls' team.

${ }^{80}$ D.M. v. Minn. State High Sch. League, 917 F.3d 994, 1004 (8th Cir. 2019).

${ }^{81} \mathrm{Id}$. at 1001 (stating that data for 2017-18 showed boys were actually the underrepresented sex by 0.35 percentage points).

82 Id. at 1002.

83 Settlement Allows Minnesota Boys to Dance Competitively, AP NEws (Apr. 29, 2019), https://www.apnews.com/ff8c21d045aa4ec18996321021ef71af [https://perma.cc/ZQP5-9QS4]. 
ruling in Attorney General v. MIAA that the state athletic association's rule banning boys from girls' teams violated the state constitution's Equal Rights Amendment remains unique. Other courts assume that recognizing boys' rights to crossover participation would threaten girls' opportunities because girls would not be able to hold on to them in an open tryout. ${ }^{84}$ The Massachusetts Supreme Judicial Court pushes back against this narrative with concern for the generalization it embodies. ${ }^{85}$

In acknowledging the potential for girls to hold to their own against boys, or at least its rejection that the concern of protecting girls' opportunities requires such a blunt tool as boys' categorical exclusion, the Supreme Judicial Court did more than acknowledge the legal right of a handful of boys who are so devoted to sports like field hockey, volleyball, or swimming, that they are willing to try out for a girls' team. Its pushback against the protectionism rationale for segregation also provides legal support for athletic opportunities that are organized without regard to athletes' gender, especially where such gender-free opportunities are included in a menu of diverse athletic offerings, some of which are segregated and some of which are not. While it invited consideration of other integration techniques like height- weight- and skill-based classifications, or gender-neutral systems of "handicapping, ${ }^{86}$ the Supreme Judicial Court also acknowledged that some sports might be more suitable for integration than others. ${ }^{87}$ Yet the MIAA's response to the Supreme Judicial Court's decision was to remove the blanket restriction on boys' participation on girls' teams, allowing students of either sex to try out for the cross-sex team if that is the only team in their sport. ${ }^{88}$ It has never seriously accepted the Supreme Judicial Court's invitation or roadmap for progressing beyond minimal compliance with its decision and imagining more integrated possibilities for high school sports.

\footnotetext{
${ }^{84}$ See Williams, 998 F.2d at 172-76.

${ }^{85}$ Mass. Interscholastic Athletic Ass'n, 393 N.E.2d at 290 ("[E]ven if equal rights provisions could be viewed primarily as a means of eradicating discrimination against women, they tend to protect men as well, because disadvantages suffered by males are often premised on a "romantic paternalism" stigmatizing to women.").

86 Id. at 295.

87 Id. at 295 ("The defendants offer . . . a connection between the presence of male athletes on a team with injury to females. It is replete with stereotypical assumptions and generalities. . . . But if we were to indulge an assumption of such a relationship in the rougher sports, what of golf, gymnastics, riflery, skiing, track, cross-country running, swimming, tennis? Risks are not constant." (Citations omitted)).

${ }^{88}$ MIAA HANDBOOK, supra note 1, at 42 . Rule 43.1 of the MIAA's Rules and Regulations Governing Athletes states:

No student shall be denied in any implied or explicit manner the opportunity to participate in any interscholastic activity because of gender. A school may establish separate teams for males and females for interscholastic competition in a sport provided that both teams receive equal instruction, training, coaching, access to available facilities, equipment, opportunities to practice and compete.

Id.
} 


\section{BENEFITS OF GENDER-FREE ATHLETIC PARTICIPATION}

Despite the Attorney General v. MIAA court's refusal to accept the categorization of all girls as athletically inferior, Massachusetts still organizes sports with protectionism in mind. ${ }^{89}$ Few boys participate on girls' teams in team sports that have traditionally been female; field hockey is the notable example. ${ }^{90}$ And when boys participate in girls' teams in individual sports, they have in the past been subject to a rule (as were girls who play on boys' teams) that redirects them into post-season tournaments that correspond to their own sex..$^{91}$

While retaining segregated opportunities in many or even most sports probably makes sense, it is notable that even with the state constitution's more permissive approach to boys and girls playing together, there have been few-if any-efforts to combine once-segregated opportunities for girls and boys into sports organized without regard to gender. Instead, opportunities for gender-free participation are as rare in Massachusetts as in any other state notwithstanding the benefits to students that would come from having at least some gender-free opportunities to choose from. This is a missed opportunity to pursue the benefits of gender-free participation. In particular, as addressed in this part, those benefits are: reducing stigma, ensuring equal treatment, and maximizing inclusion of transgender athletes.

\section{A. Segregation and Stigma}

Segregation stigmatizes women's sports and its participants by perpetuating the belief that female athletes require that a remedial version of sport must exist to accommodate them. But of course, it is possible for female athletes to be competitive and successful when they compete with and against male athletes. For example, in October 2017, a female golfer named Emily Nash-mentioned in the introduction of this Article-shot the lowest score at the Central Massachusetts boys' regional championship. ${ }^{92}$ Yet, public perception of Nash's talent would have been different

${ }^{89}$ See Mass. Interscholastic Athletic Ass' $n, 393$ N.E.2d at 288.

${ }_{90}$ Marquis, supra note 68 , at 85 (describing field hockey examples).

91 See MASS. InTERSCHOlastic Athletic Ass'n, Rules and Regulations Governing Athletics A HANDBOOK FOR PRINCIPALS AND ATHLETIC DiReCtors 42 (revised Oct. 3, 2018), http://www.miaa.net/gen/miaa_generated_bin/documents/basic_module/MIAAHandbook1719.pdf [https://perma.cc/AMG8-47SZ] [hereinafter MIAA HANDBOoK 2017-2019]. Rule 43.2.1.2 of the MIAA's former Rules and Regulations Governing Athletes states:

Students from mixed gender regular season teams will participate in the regional and state tournaments of their own gender in the sports of cross country, indoor track, outdoor track, skiing, swimming and diving, and individual tennis.

Id.

${ }^{92}$ Kay, supra note 4. 
if her high school had made the choice to sponsor a girls team. If it had, she would have competed in the girls' regular season and the girls' postseason tournament in the spring, where her victory (if she had won) would have been unremarkable. Individual examples like Nash are consistent with evidence of the tendency for women to outperform men in certain sports, and that they are closing the performance gap in others. ${ }^{93}$ In a world with more opportunities for gender-free sport, it will be easier to recognize female athleticism as just plain athleticism.

Not only would integration of sports provide more opportunities to contextualize female athleticism, it is also possible that it would permit exploration of the possibility that segregation itself is contributing to differences in performance by perpetuating self-fulfilling gender stereotypes. Segregation sends the message that "women are physically weaker" or that they "will be badly beaten and emotionally crushed" if they participate alongside men. ${ }^{94}$ These stereotypes themselves may affect the athletic performance of female athletes who internalize them. Indeed, sport scholars have shown that the concept of stereotype internalization operates in the context of athletics. ${ }^{95}$

Some coed athletic opportunities continue to perpetuate performance-affecting stereotypes with protectionist, sex-specific rules. For example, some coed sports have rules that take the sex of the player into account, whether by setting a minimum number of female players that can be on the field or imposing other sex-specific rules. ${ }^{96}$ In high school sports, a common example of coed sports is mixed double tennis, which requires that participating teams consist of one female and one male player. ${ }^{97}$ In similar fashion, some high school athletic associations endorse coed golf that is played by pairs consisting of one male and one

93 MCDONAGH \& PAPPANO, supra note 47, at 58-63.

94 Id. at 15; see also Suzanne Eckes \& Stephanie D. McCall, Channeling Billy Elliott: Legal Issues and Outmoded Stereotypes in Athletics, 366 ED. LAW REP. 578, 583 (2019) (arguing that the challenge to integrate Minnesota high school dance teams "could have been figured as a site for insisting on girls' strengths and boys would be 'allowed' to dance with them" but instead served to "us[e] sports to construct essentialized beliefs about gender differences.").

${ }_{95}$ One study noted that "there are two main pathways in which sex stereotypes manifest in sporting contexts. First, as long as it is known by the individual, a stereotype can operate directly and affect his/her performance if it is activated in a valued situation. Stereotypes can also operate indirectly, through an internalization process." Julie Boich. . . et al., Development of Sex Stereotypes Relative to Sport Competence and Value During Adolescence, 15 PSYCHOL. OF SPORT \& EXERCISE 212, 212 (2014) (citations omitted).

\% See Adam Cohen et al., Investigating a Coed Sport's Ability to Encourage Inclusion and Equality, 28 J. SPORT MGMT. 220 (2014) (noting such examples of coed football rules that require a female player to catch or pass the ball once every four downs, and coed softball rules that allow a male batter to take two bases instead of one if he is walked on four pitches); see also Catherine LeClair, Why Co-Ed Sports Leagues Are Never Really Co-Ed, DEADSPIN (July 25, 2018), https://deadspin.com/why-co-ed-sports-leagues-are-never-really-co-ed-1827699592 [https://perma.cc/DE3LDJQ8].

97 MIAA, Individual Tennis Format Sport Specific Information at 3, available at http://www.miaa.net/gen/miaa_generated_bin/documents/basic_module/tennisindividual2019format.pdf [https://perma.cc/G2N3-FTX8]. 
female player. ${ }^{98}$ While coed sports structured this way avoid some of the ways that segregation replicates stereotypes (like the unequal resources problem discussed above), they still send the message that a team with more females than another team is inherently disadvantaged. Other coed sports have sex-specific rules that reinforce the assumption that female players can't hold their own on the field, such as coed a flag football rule that a female must catch or pass the ball every four downs, or coed softball that requires the batter order to alternate by sex and that penalizes a team that walks a male batter by letting him take two bases instead of the traditional one (the assumption being that the next female in the batting order is more easily struck out). ${ }^{99}$ Additionally, some coed sports (softball, for example) are structured in ways that marginalize female players into the less critical positions and allow male athletes to usurp them (such as rules forbidding outfielders from coming in too close when females are at bat). ${ }^{100}$

Gender-free sport reduces the role of stereotype threat by validating female athleticism from the start. Removing segregation signals confidence in the ability of female athletes to hold their own, both by conveying the attitude that girls do not need to be protected from boys, and by dismantling girls-sport-specific rules that convey the message that female athletes are inferior, such as rules that allow shorter courses of play for females in golf, ${ }^{101}$ and "different rules for checking, hitting, and other movements" for women's hockey teams. ${ }^{102}$ The opportunity for boys and girls to compete together can give boys the opportunity to appreciate and respect girls' abilities. ${ }^{103}$ Sport scholars have applied intergroup contact theory to athletic participation and found evidence that diversity among teams breaks down stereotypes about race, sexual orientation, and even sex. ${ }^{104}$ In the sports that inspire lifelong participation, integration could have positive ramifications for gender equality far beyond high school athletics. For example, recreational golf is an important social lubricant for professional relationships that can serve as a source of business, mentoring, referrals, and information. ${ }^{105}$ Country clubs where recreational golf is played have historically excluded women as a result of its

\footnotetext{
98 See, e.g., Coed Golf Regulations, IOWA GiRLS High SCHOOL ATHLETIC UNION (May 22, 2018), https://ighsau.org/news/co-ed-golf-regulations/ [https://perma.cc/W2JM-WVN3].

${ }^{99}$ Cohen et al., supra note 96 , at 222.

${ }^{100} \mathrm{Id}$.

${ }^{101}$ Id.

${ }^{102}$ Nancy Leong, Against Women's Sports, 95 WASH. U. L. REV. 1249, 1275-76 (2018) (describing how the different rules for men's and women's sports perpetuate the stereotype of inferior female athleticism as well as other gender stereotypes).

${ }^{103}$ Michael A. Messner \& Nancy M. Solomon, Social Justice and Men's Interests: The Case of Title IX, $31 \mathrm{~J}$. OF SPORT AND SOC. ISSUES 162, 177 (2007).

${ }^{104}$ Cohen et al., supra note 96, at 223-224, 232 (describing applications of contact theory to sport); Id. at 232 (finding that the gender-free sport of quidditch promoted positive stereotypes about female athleticism).

105 Marcia Chambers, The Unplayable Lie: The Untold Story of Women and DISCRIMINATION IN AMERICAN GOLF 5 (1995).
} 
emphasis on male corporate culture. ${ }^{106}$ And while such policies are rare today, pervasive negative stereotypes about female golfers still undermine their opportunities to participate. ${ }^{107}$ Men whose high school teammates were female will be less likely to support and perpetuate these formal and informal barriers. ${ }^{108}$ They will be less likely to assume that a female colleague doesn't golf or doesn't golf well, and thus more inclined to extend an invitation to participate, thereby increasing her opportunities to cultivate relationships that lead to professional advancement and power.

The argument that educators should take seriously the risk of stigma that is unnecessarily perpetuated when we fail to narrowly tailor segregation to its protectionist purpose is aided by judicial precedent as well. Courts applying the equal protection doctrine have, in other contexts besides athletics, struck down "separate but equal" based on the stigma inherent in separation. ${ }^{109}$ Most notably, the stigma inherent in separation led the Supreme Court to rule in Brown v. Board of Education that segregating schools by race-"even though the physical facilities and other 'tangible' factors may be equal"-violated equal protection. ${ }^{110}$ Segregation "generates a feeling of inferiority" that detrimentally impairs the educational opportunities of those being excluded. ${ }^{111}$ The Court also recognized segregation's tendency to enforce inferiority when it ruled that Virginia could not defend the exclusion of women from its state military college by creating a separate leadership program for women. ${ }^{112}$ Because the Court's analysis included other tangible differences between the program, the inherent inequality of segregation was not conclusive in this case as it was in Brown. ${ }^{113}$ Nevertheless, the Court's decision-best known for its clear admonition against sex classifications based on

106 See Id. (noting that the "culture of the golf club world has always been heavily dominated by the males who are leaders in corporate and community life and who often assume leadership roles in their local country clubs as well.").

107 One such pervasive, negative stereotype is that women play more slowly because they do not drive as far. Yet because distance does not necessarily equal accuracy, the basis of this stereotype is questionable.

${ }_{108}$ See Cohen et al., supra note 96, at 221-24.

${ }^{109}$ Brown v. Bd. of Ed. of Topeka, 347 U.S. 483, 494 (1954) ("To separate [black students] from others of similar age and qualifications solely because of their race generates a feeling of inferiority as to their status in the community that may affect their hearts and minds in a way unlikely ever to be undone."); Loving v. Virginia, 388 U.S. 1, 11 (1967) ("Over the years, this Court has consistently repudiated '(d)istinctions between citizens solely because of their ancestry' as being 'odious to a free people whose institutions are founded upon the doctrine of equality. " (Citations omitted)); Reed v. Reed, 404 U.S. 71, 77 (1971) ("By providing dissimilar treatment for men and women who are thus similarly situated, the challenged section violates the Equal Protection Clause.").

${ }^{110}$ Brown, 347 U.S. at 493.

111 Id. at 494.

112 United States v. Virginia, 518 U.S. 515, 553 (1996).

113 Dana Robinson, A League of Their Own: Do Women Want Sex-Segregated Sports?, 9 J. of CONTEMP. LEGAL ISSUES 321, 336 (1998) ("In the same way that Brown incorporated an evaluation of inferiority, so also VMI incorporates an evaluation. But whether there is inferiority asserted is not necessarily conclusive. We know that inferiority is not conclusive because VMI begins by stating that inferiority is asserted, but the Court goes on with a very lengthy evaluation of other tangible and intangible factors."). 
"overbroad generalizations about the different talents, capacities, or preferences of males and females"114 is rooted in the concern that such generalizations and stereotypes contribute to the "denigration" ${ }^{115}$ of the excluded sex..$^{116}$

Yet in sports cases, concerns for denigration or stigma, when included in the courts' analyses, have played a more limited role. Still, courts have ruled against unequal treatment of girls' teams after recognizing the stigmatizing potential of tangible disparities. ${ }^{177}$ For example, the Michigan High School Athletic Association violated Title IX and the Equal Protection Clause by scheduling six girls' sports in the nontraditional season, including girls' basketball, which it scheduled in the fall instead of the traditional winter season. ${ }^{118}$ The district court found that girls were disadvantaged in such tangible ways as difficulty obtaining inseason equipment, diminished opportunities for national recognition and honors, and exclusion from promotional events and tournament opportunities that are scheduled with traditional-season athletes in mind. ${ }^{119} \mathrm{Ad}-$ ditionally, however, the court recognized the psychological impact of the scheduling decision. ${ }^{120}$ For example, depriving female basketball players of the opportunity to play their sport when the rest of the state and the nation is participating in or enjoying scholastic and collegiate basketball sends the "psychological message" that girls are "'second class' or that their athletic role is of less value than that of boys. ${ }^{121}$

In another case, the Seventh Circuit Court of Appeals recognized that girls were disadvantaged by the scheduling of the majority of their basketball games on weeknights (Monday through Thursday). ${ }^{122}$ Boys' games were scheduled on Fridays and Saturdays to maximize attendance by parents and other fans: a practice that also minimized for boys-but maximized for girls-the academic inconvenience of playing and traveling on school nights. ${ }^{123}$ in addition to these tangible disparities, the court also recognized the denigrating effect of unequal treatment: "the practice of scheduling almost twice as many boys' basketball games on primetime nights sends a message that female athletes are subordinate to their male counterparts and are 'second-class.' "124 The foregoing case illustrations

114 Virginia, 518 U.S. at 533.

${ }^{115} \mathrm{Id}$.

${ }^{116}$ Robinson, supra note 113 , at 336 .

117 See Cmtys. for Equity v. Mich. High Sch. Athletic Ass'n, 178 F. Supp. 2d 805, 838 (W.D. Mich. 2001), aff'd, 377 F.3d 504 (6th Cir. 2004), vacated, 544 U.S. 1012 (2005), aff'd, 459 F.3d 676 (6th Cir. 2006).

${ }^{118} \mathrm{Id}$. at 807 .

${ }^{119} \mathrm{Id}$. at 838 .

${ }^{120} \mathrm{Id}$. at 824,837 .

${ }^{121}$ Id. at 837 .

122 Parker v. Franklin Cty. Cmty. Sch. Corp., 667 F.3d 910, 923-924 (7th Cir. 2012).

${ }^{123} \mathrm{Id}$.

${ }^{124}$ Id. at 923 . 
show the negative effects of sex-discrimination-derived stigma in the athletics context. Degendering sport is a way to mitigate this concern.

\section{B. Unequal Resources}

One of the most recognizable downsides to separating athletic opportunities by sex is the risk that separate programs in the allocation of resources and opportunities. ${ }^{125}$ Title IX and equal protection doctrine both attempt to mitigate this risk by requiring separate programs receive equal treatment as measured by such tangible factors as the quantity of opportunities and the qualities of facilities, uniforms, equipment, schedule of competition, access to coaching, and other aspects of the program. ${ }^{126}$ Yet there is evidence that such inequalities persist. ${ }^{127}$ And when they do, they signal to girls that their athletic pursuits are not as worthy as those of boys. Title IX and equal protection doctrine require that "separate" be "equal, " 128 but in reality, it rarely is. Segregated sports facilitate inequitable allocation of resources that tend to track cultural bias in favor of men's sports. ${ }^{129}$ For example, high school booster clubs are more enthusiastic about and successful at raising funds to support boys' sports. ${ }^{130}$ Despite OCR's insistence that uneven fundraising by booster clubs does not excuse unequal treatment, unequal treatment nevertheless occurs. ${ }^{131}$ These inequities not only ensure that boys teams are better equipped to cultivate athletic talent, but also serve to make athletic opportunities more attractive to boys than to girls.

Obviously, unequal resources contribute to observed gender differences to some extent. Gender-free sports can mitigate the replication of gender stereotypes that occurs when athletic opportunities are separated by sex because they remove the structural vulnerability to inequitable

${ }^{125}$ Note, Cheering on Women and Girls in Sports: Using Title IX to Fight Gender Role Oppression, 110 Harv. L. Rev. 1627, 1630, 1633--35 (1997).

12634 C.F.R. $\$ \$ 106.31-106.42$ (2018).

127 Postsecondary athletics Title IX complaints have risen in recent years. See generally Celene Reynolds, The Mobilization of Title IX across U.S. Colleges and Universities, 1994-2014, 66 Social Problems 245, 255-56 (2019). According to one recent study, "[c]omplaints citing three athletic issues-interests and abilities (106.41c1), equal opportunity $(106.41 \mathrm{c})$, and meeting the requirements of part three of the three-part test (106.41c1-3)-represent[ed] 74 percent of the total filings in 2014." Id. at 256.

12834 C.F.R. $\$ 106.41(b-c)$ (2018).

129 See generally George, supra note 56, at 1113-32.

130 See generally Powell Latimer, Title IX compliance sometimes means turning down money, STARNEWS ONLINE (Nov. 28, 2010), https://www.starnewsonline.com/news/20101128/title-ixcompliance-sometimes-means-turning-down-money?fbclid = IwAR3UXhsKDBui7X2hg-oGJPgCggPsdRTUfJaGS-vOQYbHPh7I2knpnZw1rVY [https://perma.cc/6RX7-6H39].

${ }^{131}$ Letter from Thomas J. Hibino, Regional Director, Office of Civil Rights to Dr. Dorothy Galo, Superintendent, Hingham Public School District (Oct. 26, 2012), https://www2.ed.gov/about/offices/list/ocr/docs/investigations/01105003-a.htmlb [https://perma.cc/2ZF6-FMEU] ("Where booster clubs provide benefits or services that assist only teams of one sex, the district must ensure that teams of the other sex receive equivalent benefits and services."). 
distribution of resources. Whether its financial support comes entirely from the schools or is supplemented by third-party fundraising, a single team that is open to boys and girls alike ensures that all members have the same quality of coaching, the same opportunities for practice and competition, and the same perks and benefits that makes athletic participation attractive and enjoyable. Equal investment of resources will provide female athletes opportunities to cultivate their athletic abilities.

\section{Transgender Inclusion}

In addition to pushing back on the stigma inherent in separation, gender-free sports also reinforce the rationale for transgender inclusion, as well as provide opportunities for those who identify as non-binary to participate without having to compromise the affirmation of that identity.

Massachusetts is among several other states in which the athletic association governing high school sports provides an unqualified right to transgender students to participate in athletics in the category that corresponds to their gender identity. ${ }^{132}$ Specifically, the MIAA's policy is to rely on the gender determination made by the student's district, ${ }^{133}$ which as a matter of state law "shall mean a person's gender-related identity, appearance or behavior, whether or not that gender-related identity, appearance or behavior is different from that traditionally associated with the person's physiology or assigned sex at birth." ${ }^{134}$ At least one school district has adopted a specific policy of its own which guarantees transgender students the right to participate in athletics according to their gender identity-in addition to addressing related, off-the-field issues like inclusive bathrooms and locker room facilities. ${ }^{135}$ But even in districts

132 See, e.g., WASHINGTON INTERSCHOLASTIC ACTIVITTES ASSOCIATION, 2018-19 OfFICIAL HANDBOOK 32-33 (2018), http://www.wiaa.com/conDocs/Con1782/Handbook\%20Website.pdf [https://perma.cc/UFJ4-Q8P6]. Additionally, athletic associations in California, Colorado, Connecticut, Florida, Maryland, Massachusetts, Minnesota, Nevada, New Hampshire, New Jersey, Rhode Island, South Dakota, Utah, Vermont, Virginia, and Wyoming have similar inclusive policies, many of them modeled on Washington's. See Erin Buzuvis, As Who They Really Are: Expanding Opportunities for Transgender Athletics to Participate in Youth and Scholastic Sports, 34 LAW \& INEQ. 341, 348-50 (2016); K-12 Policies, TRANSATHLETE (last visited Jan. 7, 2020), https://www.transathlete.com/k-12 [https://perma.cc/62YH-TT6V] (listing high school policies for transgender student athletes from throughout the United States). As policies of state athletic associations, these rules create rights as a matter of private law that schools agree to uphold as a condition for membership in the associations. In some of these states, transgender students' rights that exist as a matter of private law are also protected by public law, a statute or regulatory interpretation thereof. See, e.g., CAL. EDUC. CODE $\S 221.5(f)$ (West 2018); Buzuvis, supra, at 362.

${ }^{133}$ See MIAA HANDBOOK, supra note 1, at 42. Rule 43.3.1 of the MIAA's Rules and Regulations Governing Athletes states: "A student shall not be excluded from participation on a gender-specific sports team that is consistent with the student's bona fide gender identity." Id.

${ }^{134}$ MASS. GEN. LAwS ch. 4, § 7, cl.59 (2018) (defining "Gender identity").

135 See generally Framingham High School Athletic Department, Framingham High SCHOOL ATHLETIC HANDBOOK FOR STUDENT-ATHLETES, COACHES, AND PARENTS 4-5 (20192020), https:/www.framingham.k12.ma.us/cms/lib/MA01907569/Centricity/Domain/81/20182019\%20SY\%20Meetings/05.01.19/V.\%20E. \% 20\%20FHS\%20Athletics \%20Handbook. docx.pdf 
that have not adopted such a policy, the state law itself creates the expectation that school officials would acknowledge a transgender student's affirmed gender identity for all purposes, including athletics.

\section{Benefits to Transgender Youth}

Thus, in Massachusetts-and in the other states whose athletic associations have similarly inclusive policies-a transgender athlete's participation in the category that matches their gender identity is unqualified: it is not subject to any special considerations, such as safety or competitive equity, as is the case in several states. ${ }^{136}$ It is also not conditioned on any particular medical intervention, such as hormone treatment, as policies in other states require ${ }^{137}$ In reality, this means a transgender girl is permitted to play girls' sports, and a transgender boy has the same rights with respect to boys' sports. Such inclusion affirms the athlete's gender identity and thus serves as a powerful source of socioemotional support. It also serves as a protective factor against psychological and emotional damage, including depression, anxiety, and self-harm, to which transgender youth are vulnerable. ${ }^{138}$ On the other hand, excluding a

[https://perma.cc/55GF-68PJ] [hereinafter FRAMINGHAM HANDBOOK] (stating the school's "Inclusive Sports Participation Policy"); Jim Haddadin, Framingham: New School Policy Supports Transgender Athletes, METROWEST DAlLY NEwS (Mar. 13, 2018), http://www.metrowestdailynews.com/news/20180313/framingham-new-school-policy-supports-transgender-athletes [https://perma.cc/6G4E-ABG8].

136 See, e.g., MAINE PrIncipals' Association, HANDBOOK 19-21 (2019-2020), http://www.mpa.cc/images/pdfs/handbook1920.pdf [https://perma.cc/2J3W-P8P4]; NEW JERSEY STATE INTERSCHOLASTIC ATHLETIC ASSOCIATION, NISIAA \& NJSCA COACHES HANDBOOK 2022 (2019--2020), https://www.njsiaa.org/sites/default/files/document/Coaches\%20Handbook\%202019-2020.pdf [https://perma.cc/5PQA-JJRE].

137 See, e.g., NeBRASKa SCHOOL ACTIVITIES AsSOCIATION, CONSTITUTION \& BYLAwS, GendER PARTICIPATION POLICY 34-37 (2019-2020), https://nsaa-static.s3.amazonaws.com/textfile/yb/bylaws.pdf [https://perma.cc/2JQL-VH3D]. Athletic associations in Delaware, Idaho, Missouri, New Mexico, North Dakota, Ohio, Oklahoma, Oregon, Wisconsin also have policies that require medical transition. See Buzuvis, supra note 132, at 345-46; For a critique of policies that require hormone treatments as a condition for transgender student's participation in athletics that correspond to gender identity, see $i d$. at $364-74$.

In Texas, for school athletics, a student's gender "shall be determined based on [the] student's birth certificate." UNIVERSITY INTERSCHOLASTIC LEAGUE, CONSTITUTION AND CONTEST RULES, NON-DISCRIMINATION POLICY 53 (2019-2020), https://www.uiltexas.org/files/policy/2019-2020full-uil-constitution.pdf [https://perma.cc/L2WP-YD36]. Five other states-Alabama, Indiana, Louisiana, Kentucky, North Carolina-limit an athlete's participation to the designation on their birth certificate, effectively prohibiting transgender students from competing according to their gender identities, while the remaining state athletic associations have either no policy or a policy of leaving it up to individual schools to decide. See Buzuvis, supra note 132, at 343-45; for a critique of these policies, see id. at 352-63.

138 See M. Dru Levasseur, Gender Identity Defines Sex: Updating the Law to Reflect Modern Medical Science Is Key to Transgender Rights, 39 VT. L. REV. 943, 957-58 (2015) (citing an amicus brief prepared by the American Academy of Pediatrics and other leading medical organizations, in support of a transgender student's case challenging her exclusion from facilities that correspond to her gender identity); Arnold H. Grossman \& Anthony R. D'Augelli, Transgender Youth and LifeThreatening Behaviors, 37 SUICIDE \& LIFE-THREATENING BEHAVIOR 527, 534-35 (2007); GABE MURCHISON, HUMAN RIGHTS CAMPAIGN, SUPPORTING AND CARING FOR TRANSGENDER CHILDREN 12-17 (Sep. 2016), https://assets2.hrc.org/files/documents/SupportingCaringforTransChildren.pdf 
transgender student from the sports that match their gender identity, as well as imposing requirements on their participation that do not apply to other students, stigmatizes them and contributes to the potential for psychological harm. ${ }^{139}$ In addition, exclusionary policies that restrict an athlete's gender-identity-based participation would likely deter many transgender athletes from participating in sports altogether. Thus, inclusive policies maximize opportunities for transgender students to attain the benefits of athletic participation on one's physical health, character, academic performance, peer relationships, and self-esteem-a privilege owned by other students. ${ }^{140}$

Yet despite these powerful benefits to transgender athletes themselves, critics of their inclusion-particularly the inclusion of transgender girls in girls' sports-have argued that opening up girls' sports to participation by transgender girls is unfair to their cisgender competitors because it puts the latter at a competitive disadvantage. ${ }^{141}$ Just as legislators in the 1970s assumed that girls needed protection from the dominance of boys, whom they deemed categorically superior athletes solely by virtue of their sex, these critics also. view transgender girls as categorically superior athletes solely by virtue of their having been assigned male at birth. ${ }^{142}$ But the Supreme Judicial Court's decision in Attorney General v. Massachusetts Interscholastic Athletic Association rejected the idea that girls are categorically and always in need of protection from the participation of boys-a holding that logically extends to support the inclusion of transgender girls as well. ${ }^{143}$ Thus, in Massachusetts (of all states), because of its exceptional state constitutional law permitting boys to play on girls' teams, arguments against the participation of pre-transition transgender girls are particularly out of place. By normalizing coed competition, the existence of gender-free athletic opportunities would by extension render transgender girls' inclusion less controversial and might therefore encourage more transgender girls to avail themselves of the

[https://perma.cc/KX28-QJSY] (position statement of the American College of Osteopathic Pediatricians and the American Pediatric Osteopathy Association).

139 Adams v. Sch. Bd. of St. Johns Cty., 318 F. Supp. 3d 1293, 1306-07 (M.D. Fla. 2018) (acknowledging the stigma in excluding transgender students from facilities that correspond to their gender identities); M.A.B. v. Bd. of Educ. of Talbot Cty., 286 F. Supp. 3d 704, 725 (D. Md. 2018) (finding that the exclusion of a transgender student from the locker room that corresponds to his gender identity is harmful to the student, because it interferes with the student's gender transition and thus exacerbates gender dysphoria).

${ }^{140}$ See Richard Bailey, Evaluating the Relationship between Physical Education, Sport and Social Inclusion, 57 EDUC. REV. 71, 80 (2005); Michael W. Beets \& Kenneth H. Pitetti, Contribution of Physical Education and Sport to Health-Related Fitness in High School Students, 75 J. SCH. HEALTH 25, 28 (2005); Russell R. Pate et al., Sports Participation and Health-Related Behaviors Among US Youth, 154 ARCH. PEDIATRIC \& ADOLESCENT MED. 904 (2000).

141 See generally Yannis Pitsiladis et al., Beyond Fairness: The Biology of Inclusion. for Transgender and Intersex Athletes, 15 CURRENT SPORTS MED. REPORTS 386 (2016).

142 See, e.g., Sangree, supra note 56, at 417-18 (discussing the legislators' paternalistic motivations in passing Title IX); Michael J. Lenzi, The Trans Athlete Dilemma: A Constitutional Transgender Student-Athlete Polices, 67 AM. U. L. REV. 841, 843-44 (describing two examples of transgendered students-athletes winning a competition and generating controversy).

143 See Mass. Interscholastic Athletic Ass' $n, 393$ N.E.2d at 294-95. 
opportunity.

Finally, the option to engage in gender-free sports could promote participation among transgender girls and transgender boys by giving them an alternative to what in some cases might be inferior alternatives. Sometimes transgender athletes, particularly transgender female athletes, are criticized and harassed for asserting their right to compete with girls. ${ }^{144}$ A gender-free option would minimize this risk while still providing an alternative to the potentially delegitimizing experience of competing in one's natal'sex category.

\section{Benefits to non-binary students}

Not all transgender students identify as male or female. In fact, there are likely more transgender students who identify themselves as something other than male or female, such as non-binary or genderqueer, than there are transgender students who do identify as male or female. ${ }^{145}$ Yet, transgender students in this category are often an afterthought in discussions about their inclusion in sport, which mostly focus on when and whether a transgender individual who identifies as male or female can participate on teams that correspond to that gender. This does not mean non-binary students are entirely excluded from athletic participation, since inclusive and exclusive policies alike would permit non-binary students to at least participate on the teams that match their birth or legal sex. ${ }^{146}$ But in light of the fact that nearly all high school athletic opportunities are designated as male or female, non-binary athletes, unlike other athletes, almost never have the option to participate in athletics in a category that validates their gender identity. ${ }^{147}$ The introduction of some gender-free options would give non-binary athletes the option to participate in a manner that does not create the dissonance between the activity's gendered context and the athlete's sense of self. ${ }^{148}$

144 See, e.g., Katie Barnes, They Are Champions, ESPNW (May 29, 2018), http://www.espn.com/espnw/feature/23592317/how-two-transgender-athletes-fighting-competesports-love [https://perma.cc/NT35-WFQY] (describing public criticism faced by transgender female athlete).

${ }^{145}$ Esther L. Meerwijk \& Jae M. Sevelius, Transgender Population Size in the United States: A Meta-Regression of Population-Based Probability Samples, 107 AM. J. PUB. HEALTH e1, e6 (Feb. 2017).

146 Some inclusive policies go further and permit non-binary students to choose whichever category feels like the best fit. See, e.g., FRAMINGHAM HANDBOOK, supra note 135, at 4-5.

${ }_{147}$ Caroline Voyles, Sex Segregation in Sport: A Denial of Rights and Opportunities for Health, HEALTH \& HUM. RTS. J. (June 28, 2019), https://www.hhrjournal.org/2019/06/sex-segregation-insport-a-denial-of-rights-and-opportunities-for-health/ [https://perma.cc/7CR7-VPCP].

148 Jessica A. Clarke, They, Them, and Theirs, 132 HARV. L. REV. 894, 967 (2019) ("The best way to accommodate non-binary athletes may be incremental moves toward eliminating sex classifications in sports."); Erin Buzuvis, Hormone Check: Critique of Olympic Rules on Sex and Gender, 31 WIS. J.L. GENDER \& SOC'Y 29, 48 (2016) ("The approach of eliminating gender categories [in sporting events] would also be inclusive of those individuals whose gender-identities are non-binary 
Transgender students may have expanding opportunities to easily change their legal sex to non-binary-a change that, while positive in many ways, could theoretically limit their legal rights to access athletic opportunities designated by binary gender category. The state of California for examplepermits those citizens with a non-binary gender identity to amend the gender designation on their birth certificates to a non-binary designation. ${ }^{149}$ Additionally, California state law already permits transgender students to participate in athletics in a manner "consistent with his or her gender identity, irrespective of the gender listed on the pupil's records. "150 It is possible that a non-binary student's decision to amend their birth certificate to list their non-binary gender designation could create confusion over which athletic opportunities are appropriate for the students, since technically, neither girls' nor boys' sports are consistent with either the student's gender identity or the gender listed on their records, depending on what "records" the school official decided to consider. To be sure, a school district's decision to prohibit a non-binary student from participating in both boys' and girls' athletics altogether would absurdly and unnecessarily pervert the spirit of the laws in California, designed to maximize inclusion and recognition for all transgender individuals, including those who identify as non-binary. ${ }^{151}$ But gender-free athletic options would mitigate the vulnerability of nonbinary students to this exclusion by ensuring some athletic opportunities would remain available even if a school official chose to interpret the law in this restrictive way. More importantly, the promotion of gender-free athletic opportunities would be an appropriate response to the increasing legal recognition of non-binary identities because laws that legalize nonbinary gender designations are responsive to, and promoting of, an understanding of the complexity of gender and recognition of the limitations of only two categories.

\section{DEGENDERING SPORT: START WITH GOLF}

While acknowledging that some degree of separation is warranted to ensure that athletic opportunities are preserved for girls, this Article has so far pushed back on the idea that all opportunities must be separated. Gender-free athletic options are consistent with Massachusetts constitutional law, 152 mitigate stereotypes about female inferior athleticism,

\footnotetext{
or fluid.").

${ }^{149}$ See S.B. 179, 2017 Leg., Reg. Sess. (Cal. 2017).

${ }^{150}$ CAL. EduC. CODE $\$ 221.5(f)$ (West 2018).

151 See, e.g., Gender Recognition Act, S.B. 179, 2017-18 Sess. (CA 2017) ("It is the policy of the State of California that every person deserves full legal recognition and equal treatment under the law and to ensure that intersex, transgender, and nonbinary people have state-issued identification documents that provide full legal recognition of their accurate gender identity.").

${ }^{152}$ See supra Part I.
} 
promotes equal treatment of athletes within the same sport, and reflect the principles and best practices of transgender inclusion.153 But as a practical matter, how do we determine which opportunities are appropriate for continued segregation, and which should be integrated and designated for all athletes regardless of gender?

To answer this question, sport organizers should consider the extent to which girls' participation currently benefits from protectionism inherent in segregation, as well as whether changing to an integrated model has the potential to enhance participation, such as by removing structural inequalities that could be suppressing girls' interest. If separation in a given sport contributes relatively little to girls' current participation, and integration offers high potential to improve girls' participation, then this sport is a good candidate for integration. This part will apply this formula to the sport of high school golf as it is played in Massachusetts and conclude that the sport is a good candidate to be reorganized without regard to participants' gender.

\section{A. Few Female Golfers Currently Benefit from Protectionist Segregation}

The reason schools segregate sports by sex is to ensure that girls have similar opportunities as boys to benefit from athletic participation. Historic and continued discrimination that can reasonably be expected to have impaired their interests and abilities, as well as generalized physical differences that could disproportionately disadvantage girls in some athletic opportunities if those opportunities were distributed without regard to gender on basis of talent alone. Recent surveys reflect that boys already receive the majority of high school athletic opportunities, both nationally (approximately 57\% for the 2018-2019 school year) ${ }^{154}$ and in the state of Massachusetts (approximately 51\% for the 2018-2019 school year), ${ }^{155}$ highlighting the particular importance of protecting girls' existing opportunities. Nevertheless, while girls' sports are important to that end, segregation is not the only way to ensure girls' participation. Exclusions based on sex should be narrowly-tailored per the Supreme Judicial

153 See supra Part II.

154 KARISSA L. NIEHOFF, NAT'L FED'N OF HIGH SCH. ASS'NS, 2019-20 NFHS HANDBOOK 54 (2019), https://www.nfhs.org/media/1020439/2019-20-nfhs-handbook.pdf [https://perma.cc/EXK7-F6G2]. This figure was calculated by dividing the number of boy survey participants from 2018-19 by the total number of participants. See id.

155 MASS. INTERSCHOl.ASTIC ATHLETIC ASS'N, 2018-2019 AtHletics PARTICIPATION Survey (last visited Jan. 22, 2020), http://www.miaa.net/gen/miaa_generated bin/documents/basic module/ParticipationSurveyOverview201819.pdf [https://perma.cc/83J7-3W96] [hereinafter $\overrightarrow{\text { MIAA }}$ PARTICIPATION SuRveY]. This figure was calculated by dividing the number of boy survey participants from $2018-19$ by the total number of participants. See id. 
Court's analysis in Attorney General v. MLAA. ${ }^{156}$ Tactics like degendering select sports, which do not threaten to diminish existing opportunities, should be considered.

Girls are already an extreme minority among Massachusetts high school golfers. There were 670 of them for the 2018-2019 school yearthe most recent year for which complete data is available-compared to 4212 boys. ${ }^{157}$ Many high school sports are dominated by one sex or the other. ${ }^{158}$ For example, girls make up less than $1 \%$ of all Massachusetts high school football players. ${ }^{159}$ But golf, in which girls constitute approximately $13 \%$ of all participants, ${ }^{160}$ experiences this gender imbalance even though it is both a boys' and girls' sport. ${ }^{161}$

\section{B. The (Former) Tournament Rule Discriminated Against Girls on Boys Teams}

Moreover, there is reason to suspect that girls' interests and abilities in golf, reflected in their low participation noted above, are suppressed by structural differences that would not exist if golf was organized as a gender-free opportunity. One clear example of discrimination against female golfers was recently addressed by the MIAA when it changed the rule that required female golfers who play on boys' teams to nevertheless participate in the girls' post-season individual tournament, which takes place in a different season than the boys' ${ }^{162}$ Former rule 43.2.1.2 was intended to protect girls' athletic opportunities: because it also prohibited boys on girls' teams from competing for an individual post-season title against girls, it ensured that only girls can compete for the girls' individual championships. ${ }^{163}$ It also arguably protected girls' opportunities by allowing them to bypass the boys' post-season tournament and compete individually in a post-season girls' tournament instead. Yet however well intentioned, the rule discriminated against female golfers. The girls'

${ }^{156}$ Mass. Interscholastic Athletic Ass'n, 393 N.E.2d at 296.

157 MIAA PARTICIPATION SURVEY, supra note 155 , at 1.

158 See Id.

${ }^{159}$ Id. This figure was calculated by dividing the total number of girls reported to be playing football by the total number of football players.

${ }^{160} \mathrm{Id}$. This figure was calculated by dividing the total number of girls reported to be playing golf by the total number of golf players.

${ }^{161}$ Some other sports with both boy and girl participants have a higher proportion of girls to boys than that in golf. For instance, for 2018-2019, girls constituted approximately $22 \%$ of all rugby players, and approximately $23 \%$ of all ice hockey players. $I d$. There are also sports-such as field hockey-in which girls significantly outnumber boys. Id.

${ }^{162}$ See Craig Larson, MIAA Revises Rules on Mixed-gender Teams, Boston GLOBE (Sep. 26, 2018), https://www.bostonglobe.com/sports/highschools/2018/09/26/schnotes/TZzK2qBBPx0yqjhZqDielM/story.html] [https://perma.cc/Y79FWU9N].

163 See MIAA HANDBOOK 2017-2019, supra note 91. Before the Oct. 3, 2018 revision, Rule 43.2.1.2 included references to "individual golf . . . ." Larson, supra note 162. 
regular season is in the spring, which meant that any female golfer on a boys' team must defer their individual title aspirations for an entire season. ${ }^{164}$ Also, because the high school post-season tournaments in Massachusetts serve to determine both team and individual champions, girls could in fact participate in the tournament, but only in the limited capacity as a member of her team. ${ }^{165} \mathrm{~A}$ girl who happened to play well in that capacity might help her team but would be ineligible for individual awards that her score would have entitled her to had she been a male member of her team. ${ }^{166}$

This is precisely what happened to Emily Nash on October 24, 2017, when she competed in the Division III boys golf Central Mass regional tournament in Uxbridge, Massachusetts. ${ }^{167}$ That day, shooting from the back tee, Nash shot 3 below a par of 75-the lowest score of the tournament. ${ }^{168}$ Yet the male athlete who took four more strokes than Nash was awarded the individual regional championship and the opportunity to move on to the state championship. ${ }^{169}$ This outcome took the media by surprise, and stories about the girl denied the championship title she had clearly earned spread quickly around the world, ${ }^{170}$ especially the world of golf. ${ }^{171}$ The disputed fact that Nash and her coach knew or

164 The MIAA Golf Committee reiterated this rule in the 2017 Boys' Fall Golf Sport Specific Information, which states-as a rule for 2017 boys' Fall golf sectional/state tournaments-that "[g]irls playing on a fall boys team CANNOT BE ENTERED IN THE BOYS FALL INDIVIDUAL TOURNAMENT. THEY CAN ONLY PLAY IN THE BOYS TEAM TOURNAMENT If qualified, they can play in the spring Girls Sectional and State Championships." MASS. INTERSCHOLASTIC Athletic ASS'N, 2017 BOYS' FALl GOlF SPORT SPECIFIC INFORMATION 5 (Oct. 11, 2017), http://miaa.net/gen/miaa_generated_bin/documents/basic_module/golffall2017format.pdf

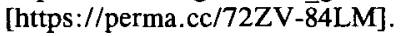

${ }^{165} \mathrm{Id}$.

$166 \mathrm{Id}$.

${ }^{167}$ Lunenburg Girl Won a Boys' Golf Tournament but Was Denied the Trophy, BosTON GLOBE (Oct. 25, 2017), https://www.bostonglobe.com/sports/high-schools/2017/10/25/lunenberg-emilynash-won-boys-golf-tournament-but-was-denied-winner-trophy-because-she-girl/WtZDRnhPDe8rd7Bv5vMJ5J/story.html [https://perma.cc/65L7-N73B].

${ }^{168} \mathrm{Id}$.

169 Camila Domonoske, Winner Of High School Golf Tournament Denied Trophy, Because She's A Girl, NAT'L PUB. RADIO (Oct. 26, 2017), https:/www.npr.org/sections/thetwoway/2017/10/26/560210230/winner-of-high-school-golf-tournament-denied-trophy-because-shes-agirl [https://perma.cc/STU7-W7TT].

170 See Callum Borchers, A High School Athletic Association Took Away Emily Nash's Golf Trophy, Then Somehow Made Things Worse, WASH. POST (Oct. 27, 2017), https://www.washingtonpost.com/news/the-fix/wp/2017/10/27/a-high-school-athletic-association-took-away-emilynashs-golf-trophy-then-somehow-made-things-worse/?utm_term $=.96 \mathrm{ac} 23 \mathrm{c} 39698$ [https://perma.cc/SQ8B-ELXZ]; Domonoske, supra note 169; James Gordon, High School Golfer Is Not Awarded First-Place Trophy After Winning a Tournament-Because She's a Girl, DAILY MAIL (U.K.) (Oct. 25, 2017), https://www.dailymail.co.uk/news/article-5017901/High-schoolgirlgolfer-not-awarded-place-trophy.html [https://perma.cc/JCE7-ZDBD]; Kay, supra note 4; National Outcry After Nash Ruled Ineligible for Golf Title, WORCESTER SENT. \& ENTER. (Jan. 1, 2018), http://www.sentinelandenterprise.com/highschoolsports/ci_31562283/national-outcry-after-nashruled-ineligible-golf-title [https://perma.cc/8C49-FLVY].

171 T.J. Auclair, Emily Nash, Who Was Denied Trophy in Boys' Toumament She Won, Receives Invitation to Annika Invitational, PGA (Oct. 31, 2017), https://www.pga.com/news/golfbuzz/emily-nash-who-denied-trophy-in-boys-tournament-won-receives-invitation-annika

[https://perma.cc/UR26-Q8H5]; Bill Speros, Outrage Grows as High School Golfer Emily Nash Gets No Relief from Massachusetts Rules Committee, GoLFWEEK (Oct. 26, 2017), 
should have known about the rule, ${ }^{172}$ as well as the fact that Nash would have an opportunity to compete for an individual title in the girls' tournament held in the spring, did little to mitigate criticism of the Massachusetts Interscholastic Athletic Association for the unfair outcome of the Division III tournament.

Nash was not even the first female golfer negatively affected by former Rule 43.2.1.2. In 2005, Lindsey Thomka, a member of the boys' golf team at Springfield's Cathedral High School, sued the MIAA for the right to participate as an individual in the boys' post-season tournament notwithstanding Rule 43.2.1.2. ${ }^{173}$ Then, as now, the MIAA sponsored boys' regional and state tournaments in the fall to determine team and individual post-season champions, while a state tournament for girls was held in the spring. ${ }^{174}$ The Cathedral team's overall performance in the regional tournament did not qualify it for advancement to the state tournament, but Thomka individually earned the fourth-best score. ${ }^{175}$ Based on that performance, she would have had the opportunity to continue on and compete for the individual title if she had been a boy, but former Rule 43.2.1.2 prohibited her from doing so. ${ }^{176}$ Instead, MIAA officials insisted that Thomka's opportunity to compete for an individual title would have to wait for spring when the girls' tournament took place. ${ }^{177}$ This exclusion prompted Thomka's lawsuit, which resulted in a preliminary injunction that allowed her to compete in the boys' tournament. ${ }^{178}$ In response to the court's order, the MIAA accepted Thomka into the tournament and sua sponte suspended the rule that required girls to play from the front tees. ${ }^{179}$ Thomka competed in the state tournament from the back tees, and she finished the tournament in last place. ${ }^{180}$

In 2007, the superior court in Hampden County issued a permanent injunction against former Rule 43.2.1.2-as it applies to female golfers-

http://golfweek.com/2017/10/26/outrage-grows-as-high-school-golfer-emily-nash-gets-no-relieffrom-massachusetts-rules-committee/ [https://perma.cc/ZZJ3-WQ4L].

${ }_{172}$ Nash told one reporter that she "wasn't aware, until after [her] round that if [she] won, [she] wouldn't be able to get the title or the trophy." Bill Doyle, Lunenburg's Emily Nash 'disappointed' with MIAA rule preventing her from winning Division 3 golf title, TELEGRAM \& GAZETTE (Oct. 25, 2017), https://www.telegram.com/sports/20171025/lunenburgs-emily-nash-disappointed-withmiaa-rule-preventing-her-from-winning-division-3-golf-title [https://perma.cc/6EZL-6QYU].

173 Thomka v. Mass. Interscholastic Athletic Ass'n, No. 051028, 2007 WL 867084, at *1-4 (Mass. Super. Ct. Feb. 12, 2007), aff' $d$ in part, vacated in part, 952 N.E.2d 462 (Mass. App. Ct. 2011).

174 ld. at $* 2$.

175 Id. at *3.

${ }^{176} I d$, at *5.

${ }^{177}$ Id. at $* 1-2$.

178 Id. at *3.

179 Thomka's lawsuit did not challenge either the MIAA's general rule restricting her to the front tees, nor did she challenge the decision to suspend the rule and make her play from the back tees in the state tournament. Id. at *3-4.

180 Id. at $* 4$. 
on the grounds that it violated the state constitution's ERA. ${ }^{181}$ As the court saw it, the rule was facially neutral because it appeared to provide "equal opportunities for male and female athletes to compete for individual, as well as team championships, in their respective sports." ${ }^{182}$ But its application is disadvantageous to female golfers whose schools choose only to sponsor a fall team. Those girls are denied an opportunity to compete for an individual title "against the same level of competition and some of the same competitors they faced through the fall season when their skills are their sharpest after having been honed by a season of camaraderie, coaching, and competition." ${ }^{183}$ The court acknowledged that female golfers who compete on boys' teams in the fall and also play other sports in the spring are particularly inconvenienced by the delay between the regular and post-season play since they have little opportunity to practice on their own in preparation for the golf tournament. ${ }^{184}$ They might experience this interruption not only as a logistical challenge (i.e., managing the competing time demands of two post-seasons at once) but also as something that diminishes the personal significance of the post-season golf opportunities (it has lesser value to these athletes because it occurs during "softball season" or however they may view the spring). Boys have no such problem since at the time of the court's decision, the MIAA held boys' championship golf tournaments in both the spring and the fall. ${ }^{185}$ And, while the MIAA has since discontinued the boys' spring tournament, ${ }^{186}$ the disparity persists because there are no Massachusetts high schools that only sponsor a girls' golf team without offering a counterpart opportunity to boys. ${ }^{187}$ As such, all male golfers in Massachusetts compete in the fall-the same season as their individual's tournamentand the disadvantage of having one's regular team season and individual tournament scheduled in different seasons is still one that only female golfers face.

On appeal, however, the state appellate court vacated the injunction on the grounds that the plaintiff had not provided notice to the Attorney General-a required condition to litigate state constitutional claims. ${ }^{188}$ As a result, former Rule 43.2.1.2 was still in effect in the fall of 2017 when it prevented regional tournament winner Emily Nash from receiving the

${ }^{181} I d$. at $* 8$.

182 Id. at $* 6$.

183 Id. at $* 7$.

${ }^{184} \mathrm{Id}$.

185 Id. at $* 2$.

${ }^{186}$ The MIAA's current Rule 35.1.1 states, in relevant part, "[a] school may offer golf in either Fall or Spring, but the Boys Team Tournament is held in the Fall and the Girls Team Tournament is held in the Spring." MIAA HANDBOOK, supra note 1 , at 36.

187 See Mass. InTerscholastic Athletic Ass' N, Participation Survey Data (last visited Feb. 2020), http://miaa.net/con-

tentm/easy_pages/view.php?page_id $=137 \&$ sid $=38 \&$ menu_id $=214$

[https://perma.cc/L9WY-957K] .

188 Thomka v. Mass. Interscholastic Athletic Ass'n, 80 Mass. App. Ct. 1105, 2011 WL 3802192, at $* 1(2011)$. 
individual regional championship title or moving on to the state tournament. Indeed, the only rule change to come out of the Thomka case was an amendment clarifying that the rule restricting girls to hitting from the front tees only applies to the regular season. ${ }^{189}$ Even though Thomka's lawsuit failed because of a procedural issue rather than the substance of its equal protection argument, the MIAA continued to exclude girls from competing for individual titles in the premier fall tournament. ${ }^{190}$ It took the national public outcry to the tournament rule's application to Emily Nash to force the MIAA to revisit the rule. ${ }^{191}$

In October 2018, the MIAA eliminated individual golf from the tournament rule (Rule 43.2.1.2), that restricted athletes on cross-sex teams to compete only in the post-season tournaments designated for their sex. ${ }^{192}$ Now, a female golfer who participates on a boys team in the fall may still participate in the girls' spring tournament, but she may also participate in the fall boys' fall tournament as both an individual and a member of her team, to the extent she qualifies like any other golfer. Yet, because this rule was only recently changed, it nevertheless provides important context for disproportionately low (when compared to the proportion of participants) interest and participation of girls in high school

\footnotetext{
${ }^{189}$ See MIAA HANDBOOK, supra note 1 , at 67 . Rule 70.2 and 70.3 of the MIAA's Rules and Regulations Governing Athletes state:

70.2. Female golfers participating on a boys' team during the regular season play must hit

from the tee box that is placed closest (yet in front of) the tee box the boys' team is

hitting from (regardless of marker color).
}

70.3. Female golfers competing on a boys' team must hit from the boys' tees at the MIAA Divisional and State Tournaments.

Id.

${ }^{190}$ Not only did the tournament violate the Massachusetts ERA, it likely would have been found to violate Title IX if it had been challenged on those grounds as well. For one reason, the MIAA may be found to have failed to provide "equal athletic opportunity" for boys and girls, considering the MLAA's inequitable "[s]cheduling of games and practice time . . . "See 34 C.F.R. \$ 106.41(c)(3) (2018). For another, MIAA's facially neutral policy resulted in Nash being treated differently from her male teammates-had they been the top-performing tournament team members, as opposed to Nash. For one circuit court that faced a case that arose under similar circumstances to Nash's, such inequality amounted to sex discrimination in violation of Title IX. See Mercer v. Duke Univ., 190 F.3d 643, 648 (4th Cir. 1999) (holding that Duke University violated Title IX when the coach allowed a female kicker to try out and make the football team, but then excluded her from participation in the sport on the basis of her sex.); see also David S. Cohen, Emily Nash Denied Boys' Golf Trophy - Which Violates Title IX, ROLLING STONE (Oct. 26, 2017), https://www.rollingstone.com/culture/culture-sports/emily-nash-denied-boys-golf-trophy-which-violates-title-ix-115296/ [https://perma.cc/ES8U-ESXP] (applying Mercer to the tournament rule and concluding that it violates Title IX because, like Duke's treatment of Mercer, the tournament rule permits a golfer like Emily Nash to compete alongside boys but then distinguishes her and limits quality of her opportunity because of sex).

${ }^{191}$ Greg Dudek, MIAA forms committee to study rule that denied Emily Nash golf trophy, BOSTON HERALD (Dec. 8, 2017), https://www.bostonherald.com/2017/12/08/miaa-forms-committee-tostudy-rule-that-denied-emily-nash-golf-trophy/ [https://perma.cc/9JJD-3N5T]

192 See Larson, supra note 162 ("As of [Sep. 26, 2018], the words 'boys' and 'individual golf' were removed from Rules 43.2.1 and 43.2.1.2 in the MIAA Handbook regarding 'Boys' and Girls' on the Same Team.' And in the MIAA's Tournament Format for golf, the postseason is listed as '2018 Fall Golf Championship,' with no reference to gender. "); see also MIAA HANDBOOK 20172019 , supra note 91 . 
golf. For the large number of high school girls in Massachusetts, whose schools have no girls' golf team, the unequal opportunities that have persisted for girls who play on boys' teams has surely signaled the sport as less than appealing and welcoming to girls.

\section{Girls Who Play on Girls' Teams Are Disadvantaged by the Spring Season}

Another disparity that has likely suppressed girls' participation in golf-and which will continue to do so-is the scheduling of girls' golf in the spring season. Spring is a disadvantageous season for high school golf in Massachusetts. The weather in spring is less reliably suitable for golf than that in fall, ${ }^{193}$ in which golf enjoys a longer season under more advantageous conditions. ${ }^{194}$ In addition, fall is the season for college recruiting and applications. ${ }^{195}$ Similar facts about spring and fall golf led a federal district court in Michigan to conclude that the state athletic association violated Title IX because spring, the season for girls' golf for most of the state, was disadvantageous compared to the fall when boys' golf was played. ${ }^{196}$ The court found that, "In Michigan, the golf courses are in better condition during the fall season. Girls are more likely to face cold, icy weather and frozen or muddy golf course greens in the spring and do not have the advantage of starting the season on a course which has been groomed all summer. " ${ }^{197}$ Moreover, the fact that Michigan golf courses close in the winter (as they do in Massachusetts) means that "Michigan girls begin their spring high school season without the benefit of playing during the winter and score more poorly" than golfers who compete in the fall. ${ }^{198}$ Finally, "because the NCAA letter of intent signing date is in early November, Michigan boys have four years of golf experience and scores on which to be evaluated. Michigan girls only have three years because their season occurs after the letter of intent signing

193 See Rick Rendell, Snow problems wreak havoc on the start of spring sports practice, METROWEST DAILY NEWS (Mar. 21, 2016), http://www.metrowestdailynews.com/sports/20160321/snow-problems-wreak-havoc-on-start-of-spring-sports-practice [https://perma.cc/EH43-SB8R] (describing the impact of late snow on spring sports in Massachusetts); Brittney McNamara, Heavy snow and lasting winter weather delay spring sports, WICKED LOCAL (Mar. 7, 2015), http://www.wickedlocal.com/article/20150307/NEWS/150306939 [https://perma.cc/XG4L-5DV3] (describing the same problem in another year).

194 See Thomka, 2007 WL 867084, at *1. Though the court was not asked to decide whether the girls' spring season was discriminatory in light of the boys' season in the fall, it did acknowledge the disadvantage of golfing in the spring as part of its analysis of the discriminatory effect of Rule 43.2.1.2. Id. at *5-7.

195 Id. at *4.

196 Cmtys. for Equity, 178 F. Supp. 2d at 862.

${ }^{197} \mathrm{Id}$. at 832 . The district court's findings about golf and its conclusion that the MSHAA discriminated against girls by scheduling it in the spring was later affirmed by the 6th Circuit. Cmtys. for Equity, 377 F.3d at 515.

198 Cmtys. for Equity, 178 F. Supp. 2d at 832. 
date. ${ }^{199}$ To be sure, the fact (if proven) that spring is the disadvantageous season for golf in Massachusetts would not be conclusive of discrimination under Title IX and equal protection, but rather would be a component in a wider analysis of disadvantageous seasons. That said, there do not appear to be any other sports that are scheduled in different seasons for boys and girls that have raised these concerns. ${ }^{200}$

Gender-free golf is one solution that would address both the discrimination that results from scheduling the girls' regular season at a disadvantageous time of year and the discrimination against female golfers on boys' fall teams whose individual post-season does not occur until spring. The MIAA could consolidate all high school golf in the fall or continue to have fall and spring seasons from which member schools could choose. Either way, limitations on available facilities would not create a gender-based disparity. All golfers would be eligible to compete for the individual title in the post-season championships that serve as capstones to the regular season.

\section{Degendered Golf Poses Minimal Risk of Reducing Girls' Participation}

For advocates of women's sports and gender equality, the biggest risk from degendering any sport is that it would diminish athletic opportunities for girls. This could happen if girls are deterred by the prospect of having to compete with and against boys. It could also happen if girls are indeed unable to survive gender-free tryouts because they are, on the whole, less competitive at the sport than boys are. Even though Emily Nash has proven that female golfers can compete with and win against boys, this is a valid and understandable concern, as it is the reason for the separate-but-equal approach in the first place. ${ }^{201}$ Yet, this risk must be properly contextualized. As noted above, an overwhelming majority of Massachusetts high schools sponsor only a boys' team, which means that most schools with golf teams already expect any girls who want to compete to surmount any disinterest in playing with or against boys, and to earn a position on the team. ${ }^{202}$ The remaining minority of schools that

\footnotetext{
${ }^{199} I d$.

200 The fact that most Massachusetts sports that are organized separately for girls and boys are generally scheduled to the same season limits the potential for a wider analysis involving additional examples of disadvantageous scheduling of seasons. Girls' volleyball is a fall sport and boys' volleyball is a spring sport, yet both of these seasons coincide with the traditional and collegiate seasons for their respective sports. As such, it is unlikely that volleyball scheduling would provide any evidence of disadvantageous scheduling affecting boys to offset the disadvantageous scheduling of girls' golf.

${ }^{201}$ See supra note 167; Mass. Interscholastic Athletic Ass'n, 393 N.E.2d at 295.

202 MIAA PARTICIPATION SURVEY, supra note 155.
} 
offer teams for girls do so in the spring season. ${ }^{203}$ Because gender-free golf could be played in the fall, it would remove the practical disadvantages that female golfers on girls' teams must overcome, as well as the stigmatizing impact of imposing these disadvantages on female rather than male golfers. The degendering of golf could have a net positive effect on girls' participation, based on these considerations alone.

In addition, however, there are two attributes of golf when played as a team sport that, if exploited, could make it particularly accommodating of female golfers on gender-free teams. One feature of team golf is that, unlike other team sports, there is no inherently ideal roster size. Other team sports have a set number of players who can compete at a time-nine in baseball, six in hockey, for example. While this number does not cap the size of the team, it serves to anchor what is generally considered an appropriate number. Rosters in those sports are therefore relatively similar in size from school to school. In team golf, however, there is great diversity in the size of teams throughout the Commonwealth. The fact that some schools have golf teams of twenty, suggests that schools with teams of only four or five could probably expand in size to accommodate more players without diminishing the opportunities of existing players. ${ }^{204}$ Such expansion would mean that degendering golf doesn't necessarily require all female golfers to displace an existing male golfer in order to make the team.

The second feature of team golf that could make it more accommodating of female golfers is that there is no paradigmatic format for team golf. Unlike baseball, for example, which is consistently played the same way, team golf is played in a variety of ways already, even within the Commonwealth. While it would be impossible to imagine changes to the rules of baseball that would maximize participation by athletes whose skills are not already selected for by the rules of the game-such changes would undermine essential aspects of the sport-team golf is not so restricted by such consistency and tradition. ${ }^{205}$ Organizers therefore have more leeway in team golf than in other sports to consider changes to the format and the scoring that could maximize participation by golfers with a diverse set of skills and abilities.

\footnotetext{
${ }^{203}$ Rule 35.1 .1 of the MIAA HANDBOOK states that "[a] school may offer golf in either Fall or Spring, but the Boys Team Tournament is held in the Fall and the Girls Team Tournament is held in the Spring." MIAA HANDBOOK, supra note 1, at 36.

204 For instance, Agawam High School has eighteen boys and three girls playing golf, Amesbury High School has eighteen boys playing golf, and Bellingham High School has twenty-one boys and one girl playing golf. MASS. INTERSCHOLASTIC ATHLETIC ASS' N, 2018-19 SPORTS PARTICIPATION BY SCHOOL 4-5, 17 (May 10, 2019), http://www.miaa.net/gen/miaa_generated_bin/documents/basic_module/MemberSchoolParticipation20182019.pdf [https://perma.cc/L9WY-957K].

${ }^{205}$ See PGA Tour, Inc. v. Martin, 532 U.S. 661, 690 (2001) (holding that permitting a golfer to use a golf cart-despite the association's walking requirement- "would not fundamentally alter the nature of petitioner's tournaments.").
} 
Individual golf, to be sure, has traditionally and is consistently played in the same way: "using clubs to cause a ball to progress from the teeing ground to a hole some distance away with as few strokes as possible." ${ }^{206}$ An individual golfer therefore needs a combination of skills: strength to drive the ball from the tee to the green and the finesse to put the green. Some of the formats for team golf are inherently based on stroke play, so that a round of golf played by all members of both teams can simultaneously determine a team winner and an individual winner. For example, sometimes teams square off in matched pairs and the team with the highest number of pair-wins is the match winner. In another team format, after all players on both teams have played the entire course, the team is awarded one point for having the player with the lowest score on the first nine holes, one point for having the player with the lowest score on the last nine holes, and one point for having the player with the lowest score overall; the team with the highest number of points wins the match.

With so much inherent diversity already in the sport of team golf, rules of team play could creatively seek to recognize a wider range of skills that might be present on an all-gender team. For example, after all players on both teams have played all 18 holes, the team winner could be determined by series of points awarded for the player who uses the fewest strokes to reach the green from the tee, the player who uses the fewest strokes from the green to the hole, and the player with the lowest score overall. This is only a slight modification from the team golf format that awards one point for each of the front-nine winner, back-nine winner, and overall winner. But it would permit a player with less physical strength, who might need two strokes to reach the green, a chance to contribute to the team's overall score of the match. A good short-game player would therefore be more valuable to the roster even if they don't drive the ball as far as the other players on the team. A coach putting together a team would take this into account when deciding who can play, with the result being a more physically-diverse team that naturally is more gender diverse as well.

\section{CONCLUSION}

On its face, Attorney General v. MIAA secures a limited right of boys to play on girls' teams. ${ }^{207}$ But more fundamentally, it is a decision that rejects the knee-jerk unqualified protectionism that justifies the segregation of sports by sex. Arguably, it is a case that should have inspired 
more creative alternatives to segregation than it has in fact. On the occasion of the decision's fortieth anniversary, it makes sense to reconsider the paradigm of segregation in sport.

This article contributes a modest and practical proposal that accepts the invitation extended by the Supreme Judicial Court forty years ago to ensure that segregation is tailored as narrowly as possible to secure protection of girls' athletic opportunities. Without abandoning segregation altogether, it is possible to start to examine it critically and seek to scale it back where possible. Golf represents one concrete example of a sport in which girls may have more to gain than lose by removing the segregation in that sport. More fundamentally, the process of examination that is reflected in Part IV can serve as a model for continuing to examine all sports over time.

Gender-free sports, whether golf or something else, are important to include among the options for high school athletes for three important reasons: first, they mitigate the stigma inherent in the protectionisms that female athletes are categorically inferior. Emily Nash prevailed with the lowest score in the boys' tournament and without any accommodation. But it was only because her school decided to only field a boys' golf team that she was competing in the fall tournament against male competitors. ${ }^{208}$ There could be more people like Emily Nash out there; we just don't see them because the majority of female golfers compete separately, in the spring, and only against each other. Gender-free golf would provide more opportunities for female athletes, their male teammates, and society at large to recognize female athleticism as athleticism, unqualified. Second, gender-free sports can equalize access to resources, such as in the case of golf: it is difficult for high schools to find golf courses to schedule practice and competitions for separate teams in the same season, and girls are relegated to the less advantageous spring season. Unification of two separate teams would have the practical benefit of equalizing access to resources at the most advantageous time. Finally, gender-free golf would provide more opportunities for athletes to participate without scrutiny of their sex and gender. This could be particularly advantageous to athletes who are transgender, including those who are non-binary. Transgender athletes, especially transgender female athletes, often face public scrutiny and criticism when participating in girls' sports. ${ }^{209}$ Gender-free options provide transgender athletes the opportunity to avoid this risk while still participating in athletics. Athletes who identify as other than male or female may also face similar scrutiny when participating in gendered sports. In addition, however, whereas other transgender athletes have the opportunity to select gendered sports that validate their gender identities, a non-binary athlete's opportunity for gender-validating participation is 
currently limited but would be enhanced by the addition of more genderfree opportunities.

For all these reasons, educators in Massachusetts should adhere to the forty-year old directive in Attorney General v. MIAA to ensure that segregation is narrowly tailored to its protectionist objective and should strive to degender sports wherever it makes sense to do so. 